PNL-5609

UC-70

2F

\title{
MINTEQ2 Geochemical Code: Provisionary Organic Data Base
}

\author{
J. R. Morrey \\ K. M. Krupka \\ F. H. Dove
}

October 1985

Prepared for the U.S. Department of Energy under Contract DE-AC06-76RLO 1830

Pacific Northwest Laboratory Operated for the U.S. Department of Energy by Battelle Memorial Institute 


\title{
DISCLAIMER
}

This report was prepared as an account of work sponsored by an agency of the United States Government. Neither the United States Government nor any agency thereof, nor any of their employees, makes any warranty, express or implied, or assumes any legal liability or responsibility for the accuracy, completeness, or usefulness of any information, apparatus, product, or process disclosed, or represents that its use would not infringe privately owned rights. Reference herein to any specific commercial product, process, or service by trade name, trademark, manufacturer, or otherwise, does not necessarily constitute or imply its endorsement, recommendation, or favoring by the United States Government or any agency thereof. The views and opinions of authors expressed herein do not necessarily state or reflect those of the United States Government or any agency thereof.

\author{
PACIFIC NORTHWEST LABORATORY \\ operated by \\ BATTELLE \\ for the \\ UNITED STATES DEPARTMENT OF ENERGY \\ under Contract DE-AC06-76RLO 1830
}

\begin{tabular}{|c|c|}
\hline \multicolumn{2}{|c|}{ Printed in the United States of America } \\
\hline \multicolumn{2}{|c|}{ Available from } \\
\hline \multirow{4}{*}{\multicolumn{2}{|c|}{$\begin{array}{c}\text { National Technical Information Service } \\
\text { United States Department of Commerce } \\
5285 \text { Port Royal Road } \\
\text { Springfield, Virginia } 22161\end{array}$}} \\
\hline & \\
\hline & \\
\hline & \\
\hline \multirow{2}{*}{\multicolumn{2}{|c|}{$\begin{array}{l}\text { NTIS Price Codes } \\
\text { Microfiche A01 }\end{array}$}} \\
\hline & \\
\hline \multicolumn{2}{|c|}{ Printed Copy } \\
\hline & Price \\
\hline Pages & Codes \\
\hline $001-025$ & $\mathrm{~A} 02$ \\
\hline $026-050$ & A03 \\
\hline $051-075$ & $\mathrm{~A} 04$ \\
\hline $076-100$ & $\mathrm{~A} 05$ \\
\hline $101-125$ & A06 \\
\hline $126-150$ & A07 \\
\hline $151-175$ & A08 \\
\hline $176-200$ & $\mathrm{~A} 09$ \\
\hline $201-225$ & A010 \\
\hline $226-250$ & A011 \\
\hline $251-275$ & A 012 \\
\hline $276-300$ & A013 \\
\hline
\end{tabular}


MINTEQ2 GEOCHEMICAL CODE :

PROVISIONARY ORGANIC DATA BASE

\author{
J. R. Morrey \\ K. M. Krupka \\ F. H. Dove
}

October 1985

Prepared for

the U.S. Department of Energy under Contract DE-ACO6-7 ERLO 1830

Pacific Northwest Laboratory

Richland, Washington 99352 


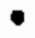

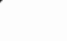

.

1

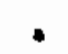




\section{ACKNOWLEDGMENTS}

We express gratitude to several people who have cooperated in the preparation of this report. First, we thank G. Sposito and S. Mattigod of the University of California, Riverside, for making their code GEOCHEM and its thermochemical data base available to us. He also are indebted to J. Serne,

J. Sonnichsen, J. Relyea, E. Jenne and R. Isaacson for valuable comments, and J. Downs-Berg for editing help. 
$\checkmark$

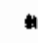

* 


\section{FOREWORD}

The program, entitled "Site Performance Assessment for the Disposal of Kanford Defense Waste," was initiated in FY 1985 to address the consequences of events and processes that might affect the waste disposal system. The program is part of the issue resolution for performance assessments as defined in the Hanford Waste Management Technology Plan (December 1984). The objectives of the program are threefold:

- to evaluate the effectiveness of various disposal options in protecting present and future humans and their environments from Hanford defense waste

- to develop and maintain the analytical techniques, models, and data bases necessary to assess postulated disposal actions on a systems performance basis

- to provide a technical basis for decisions concerning site selection, conceptual systems design, system tradeoff studies, development of criteria and standards, and research and development priorities.

One programmatic task is directed toward developing tools to understand the implications of potential aqueous transport of chemicals from a storage tank or other source to the environment. In this regard, efforts during FY 1985 have included the development of a capability to estimate the aqueous composition of sources and the solubility coefficients of contaminants with the presence of organics in solution. 


\section{EXECUTIVE SUMMARY}

Organic components in aqueous radioactive chemical sources, surface waters, and ground waters could substantially alter the mobility of radioactive and other important nonradioactive elements released from a defense waste disposal system. It is therefore important to be able to predict, as accurately as possible, the effects of selected organic components on the solubilities of radionuclides and important nonradioactive elements.

Pacific Northwest Laboratory (PNL) has developed the computer code, MINTEQ2, for the U.S. Department of Energy (DOE). This geochemical code can be used to assess solubilities provided that appropriate thermochemical data for organic and inorganic aqueous species and solids are available for its use. The code accepts an assemblage of gaseous and solid phases in contact with an aqueous phase and calculates the thermochemical equilibrium between these phases. Unlike typical hydrologic flow and transport codes where the data base is entirely site specific (i.e., parameters particular to the specific site), MINTEQ2 requires an additional generic thermochemical data base. This report discusses the addition of provisionary organic reactions and associated equ $i-$ 1 ibrium constants to the generic data base that can be used by MINTEQ2 in scoping calculations or preliminary performance assessments.

Our organic thermochemical data set was compiled from a thermochemical data set published as part of the GEOCHEM computer code by staff at the University of California, Riverside. Included in the compilation are reactions with the following organic ligands that commonly complex with metal ions and generally increase the solubility (thus mobility) of metals in water: 1) acetates, 2) citrates, 3) ethylenediamines, 4) ethylenediaminetetraacetates, 5) diethylenetriaminepentaacetates, and 6) nitrilotetraacetates. Of these ligands, only acetate, citrate, and ethylenediaminetetracetate have been indentified as major organics in Hanford defense waste. The other two, diethylenetriaminepentaacetate and nitrilotetraacetate, have not been identified to date, but they have been included to represent two other classes of organics that might be expected to form in defense waste tanks. 
The task of modifying and formatting the thermochemical data in the GEOCHEM data set to be acceptable for use in MINTEQ2 required the generation of a manipulative computer code, GEOMIN. This new code was subsequentiy used to transform the thermochemical data.

The data base for MINTEQ2 is provisionary because we have made no attempt to verify the data reported in the GEOCHEM data set and because the GEOCHEM data set did not include reactions for radionuclides. It will be necessary to accumulate additional data on the organic complexation of radionuclides from other sources in the literature. Furthermore, in the interest of economy, the final organic data base ought to be defined and verified only after all of the important organic ligands have been identified in the waste inventory and the subsurface environment. In the meantime, however, using MINTEQ2 and the provisionary organic data base to simulate problems associated with the Hanford defense waste will help to focus attention on needed additional reactions.

We recommend that MINTEQ2 be further developed to increase its chemical modeling capability to include adsorption processes and to increase its applicability to Hanford defense waste problems, such as modeling leaks from containment vessels and other waste sources and chemical processing to produce the waste. 
CONTENTS

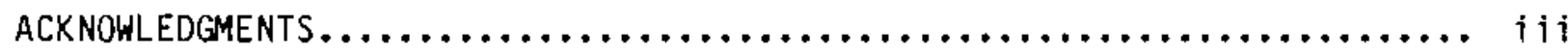

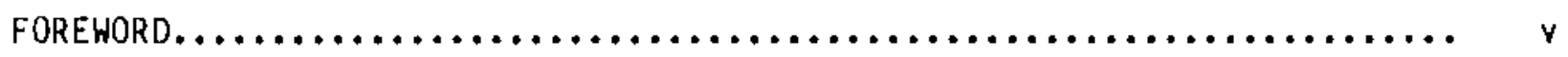

EXECUTIVE SUMMARY.......................................... vii

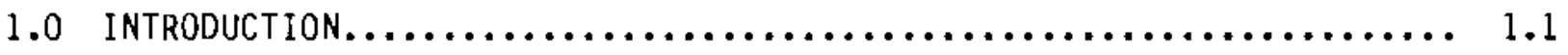

1.1 ESTABLISHMENT OF A 'BEST' THERMOCHEMICAL DATA BASE.......... 1.3

2.0 BACKGROUND $. \ldots \ldots \ldots \ldots \ldots \ldots \ldots \ldots \ldots \ldots \ldots \ldots \ldots \ldots \ldots \ldots \ldots \ldots \ldots \ldots \ldots \ldots \ldots \ldots \ldots, 2.1$

2.1 GEOCHEMICAL EQUILIBR IUM CODES $\ldots \ldots \ldots \ldots \ldots \ldots \ldots \ldots \ldots \ldots \ldots, 2.1$

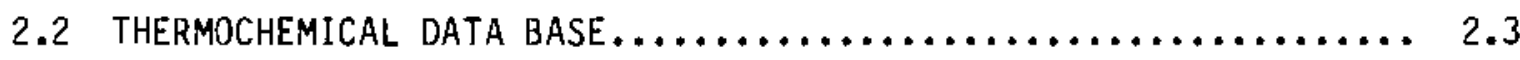

2.2.1 Previous Thermochemical Data Base................. 2.3

2.2.2 Need for Additions of Organic Ligands............... 2.5

2.2.3 Source of Organic Thermochemical Data.............. 2.5

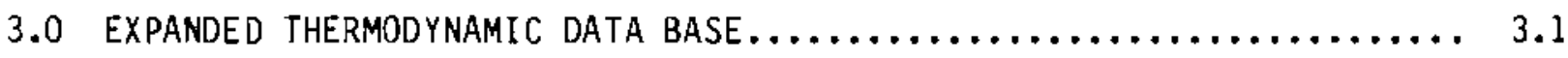

3.1 ORGANIC LIGANDS IN THE SPOSITO-MATTIGOD DATA BASE.......... 3.2

3.2 Generation OF the MinTeq2 -COMpatible data base $\ldots \ldots \ldots \ldots \ldots \ldots, 3.2$

3.2.1 Data Base Conversion........................... 3.2

3.2.2 Identification Indices for Organic Ligands........... 3.4

3.3 DEFinitions AND thermodynamic STANDARDS $\ldots \ldots \ldots \ldots \ldots \ldots \ldots \ldots, 3.6$

3.4 SELECTED ORGANIC LIGANDS............................. 3.7

3.4 .1 Acetates..................................... 3.8

3.4 .2 Citrates................................... 3.10

3.4.3 Diethylenetriaminepentaacetates.................. 3.12

3.4.4 Ethylenediamines................................. 3.14

3.4.5 Ethyl enediaminetet raacetates..................... 3.15

3.4.6 Nitrilotriacetates............................ 3.17 
3.4.7 0xalates.................................... 3.19

4.0 RECOMMENDATIONS FOR FURTHER WORK........................ 4.1

4.1 ADDING ORGANIC REACTIONS TO THE THERMODYNAMIC DATA BASE...... 4.2

4.2 ADDING PITZER PARAMETERS FOR ORGANIC INTERACTIONS $\ldots \ldots \ldots \ldots \ldots . .3$

4.3 ADDING AOSORPTION REACTIONS $\ldots \ldots \ldots \ldots \ldots \ldots \ldots \ldots \ldots \ldots \ldots, 4.3$

4.4 FURTHER MODIFICATIONS TO MINTEQ $2 \ldots \ldots \ldots \ldots \ldots \ldots \ldots \ldots \ldots \ldots, 4.3$

4.5 APPLICATIONS TO HANFORD DEFENSE WASTE PROBLEMS $\ldots \ldots \ldots \ldots \ldots \ldots 4.4$

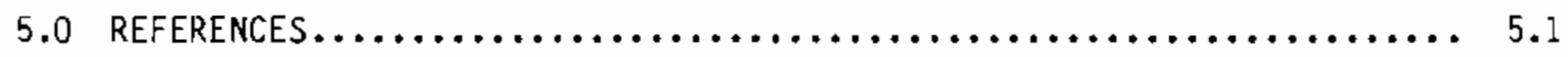

APPENDIX A - CURRENT LISTING OF DATA CONVERSION CODE, GEOMIN.......... A.l 


\section{FIGURES}

2.1 Schematic of Chemical Modeling Capabilities of MINTEQ2......... 2.3

\section{TABLES}

2.1 Listing of Thermodynamic Data Base Before Additions............ 2.4

3.1 Organic Ligands Included in the GEOCHEM Database............. 3.3

3.2 Wiswesser Group Designations.......................... 3.5

3.3 Designations for Organic Ligands..................... 3.6

3.4 Thermochemical Additions for Acetates.................... 3.8

3.5 Thermochemical Additions for Citrates..................... 3.10

3.6 Thermochemical Additions for Diethylenetriaminepentaacetates...... 3.12

3.7 Thernochemical Additions for Ethylenediamines ............... 3.14

3.8 Thermochemical Additions for Ethylenediaminetetraacetates........ 3.15

3.9 Thermochemical Additions for Nitrilotriacetates.............. 3.17

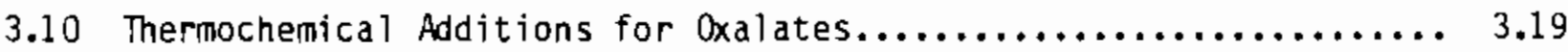

4.1 Additional Organic-Ligand Reactions Needed for MINTEQ2......... 4.2 


\subsection{INTRODUCTION}

Complex aqueous chemistry is associated with many aspects of the management of defense wastes. Problems associated with reprocessing of nuclear fuels, transfer of wastes to tanks through connecting pipes or tank cars, storage of wastes in repositories, spills or leaks, and transport rates of radioactive and hazardous nonradioactive elements through geological formations all need to be well understood to ensure adequate waste management. With systems as complex as those generally found at nuclear installations, however, the chemistry is concomitantly complex enough to require computer codes to calculate, simulate, or model the consequences of possible unplanned scenarios.

The use of chemical codes can be particularly helpful in obtaining valuable insight while interpreting laboratory or field data. Using these codes to test conceptual models of the actual physical and chemical processes can help distinguish important from unimportant factors affecting the complex chemistry. For example, modeling can be used to test the hypothesis that a certain chemical equilibrium has been attained, or conversely, determine which solid phases are not in thermodynamic equilibrium with a particular aqueous system. Codes can be used to help distinguish the relative importance of adsorption and precipitation and can identify the redox state of the system if it is not experimentally known.

One important application of geochemical equilibrium codes is in helping predict chemical behavior in storage tanks. Defense wastes are currently stored in a variety of disposal systems (e.g., single or double-shell tanks, near-surface trenches, settling ponds, etc.). Assessment of the performance of these systems requires defining the composition of aqueous solutions that could, under selected scenarios, migrate to the accessible environment. An example is the performance assessment of dewatered and liquid wastes in singleshell tanks. One scenario might be the migration of water through a rupture in the tank, dissolution of some of the salt cake or sludge, migration back out, and transport into the surrounding sediments. Another might be the direct leakage of existing liquids out of the tanks. In either case, to predict the 
migration of chemicals away from the source, we must know the initial chemical composition of the water solution at the source (source term).

The development of a source term is a critical step in the performance assessment of a waste disposal option. Although the importance of this releast: component is well established, source-term modeling is perhaps the least devel.. oped of the performance assessment analyses. Because the contaminant eventually received at the accessible environment is directly related to the released waste, source-term modeling can significantiy influence predictions of the future consequence of a contaminant release.

The source term depends on several variables: the scenario selected for contaminant release; the waste inventory; the waste form; the contaminant release rates for liquid, soljd, and gaseous phases; the ground-water chemistry; the temperature; the $\mathrm{pH}$; and the redox environment. Often, considerable: uncertainty exists regarding the actual waste inventory, contaminant release rates, and ground-water chemistry, particularly in the unsaturated zone above the water table.

The presence of organic ligands may increase contaminant solubility well beyond concentrations normally predicted by considering inorganic solubility equilibria. Multidentate ligands are effective in this regard, and EDTA, a hexadentate ligand, is particularly effective (St umm and Morgan 1970). For example, at a pH of $8,10^{-2}$ molal EDTA will increase the solubility of Fe(III) in equilibrium with ferric hydroxide by six orders of magnitude over what it would be without the presence of EDTA.

This report does not focus directly on predicting the aqueous-organic chemistry in storage tanks nor in other applications; instead, its focus is on efforts to accumulate organic thermochemical data that must be added to existing compiled thermochemical data for inorganics before reliable predictions car be made. An organic thermochemical data base is required to estimate the effect of organic chemical reactions on the complexation of other dissolved chemical species and the precipitation or dissolution (i.e., solubility) of contaminant-containing solid phases. 
Pacific Northwest Laboratory has developed a provisionary organic data base that can be used by the geochemical code MINTEQ2. The thermochemical data for reactions described herein have all been taken from a compilation that was tailored to study reactions in soil-water systems. Consequently, the origina 1 data set contains a large number of organic ligands common to soils, most of which are not expected in low-humus Hanford site soils. Therefore, only a few ligands are included in our data base. All such organic reactions must be considered provisionary because no effort has been expended to verify their accuracy or adequacy. Verification can best follow after it has been determined which organic ligands are important in the assessment of disposal systems for Hanford defense waste.

\subsection{ESTABLISHMENT OF A 'BEST' THERMOCHEMICAL DATA BASE}

Quality assurance for the thermochemical data of the reactions presented in this report will require a substantial and sustained effort. The normal process of selecting the 'best' data for a given element requires the following sequence of efforts:

- An initial collection of thermochemical data for the aqueous species, solids, and redox couples should be obtained from as many technically reputable sources as possible, including the National Bureau of Standards (NBS), the U.S. Geological Survey (USGS), the data base being assembled by the International Union of Pure and Applied Chemistry (CODATA), and data from refereed scientific journals. This collection should include fundamenta) thermochemical data (e.g., Gibbs free energies of formation, enthalpies of formation, and entropies) and reference citations for each thermochemical value.

- The collected thermochemical data should be critically reviewed and the best data selected by examining the original sources and checking the derivations of the thermochemical parameters.

- The choices should be documented. The documentation should include the references, selection criteria, recalculations or estimations, and efforts to generate an internally consistent data base. 
- Validation studies should be conducted to document the degree of agreement between modeling studies, using the best selected values, and analytical data from laboratory and field experiments and sitecharacterization studies.

The data base in its present form should be useful for scoping calculations, preliminary performance assessments, and perhaps most importantly, identifying technical areas needing more research and development. However, it: should be clearly understood that thermochemical modeling studies based on a the provisionary thermochenical data base may not be technically defensible. Until the source of each thermochemical value is known and careful evaluations have been conducted, one cannot judge the accuracy of the calculations leading to the formation of the data base. 


\subsection{BACKGROUND}

Often overlooked is the effectiveness of chemical codes in helping the user obtain valuable insight while interpreting laboratory or field data. Using these codes to test conceptual models of the actual physical and chemical processes can help distinguish important from unimportant factors affecting the complex chemistry. For example, modeling can be used to test the hypothesis that a certain chemical equilibrium has been attained, or conversely, determine which solid phases are not in thermodynamic equilibrium with a particular aqueous system. Codes can be used to help to distinguish the relative importance of adsorption and precipitation and can identify the redox state of the system if it is not experimentally known.

\subsection{GEOCHEMICAL EQUILIBRIUM COOES}

A number of sophisticated computer codes have been written to model complex aqueous chemical equilibria (Kincaid, Morrey and Rogers 1984). These have been used with varying degrees of success to predict aqueous concentrations of chemical elements in aqueous fluids as they interact with complexing ligands, soils, and sediments under the influence of a given $\mathrm{pH}$, Eh (redox potential), temperature, carbon dioxide pressure, and oxygen gas pressure (Kincaid and Morrey 1984). Some codes have also been used to predict the formation of mineral phases and changes in pH, Eh, temperature, and gas pressures; or to understand how the composition of an aqueous phase changes when the $\mathrm{pH}$, or oxygen or carbon dioxide pressure are altered by external means; or when a ligand is added to the aqueous stream.

One of the more versatile chemical codes is MINTEQ, developed by Felmy, Girvin and Jenne (1984). They combined the code MINEQL, developed by Westal1, Zachary, and Morel (1976), with the data base and other attributes of WATEQ2, developed by Bal1, Wrdstrom and Jenne (1980). MINTEQ now includes the most complete set of algorithms for adsorption and the most completely documented thermochemical data base of any of the codes for modeling geochemical equilibrium. It also has been extended to model the dissolution or precipitation of finite quantities of solids. 
MINTEQ, however, has some limitations that led us to modify it, thereby generating a follow-on version called MINTEQ2. The modifications are summarized below:

- The use of MINTEQ2 was made easier by constructing a preprocessor code to minimize errors in creating input data files.

- Convergence reliability of MINTEQ2 was improved. The Newton-Raphson technique used in MINTEQ was supplemented by deDonder shifting and back substitution (Morrey and Shannon 1981).

- The code's reliability in modeling solid systems with finite quantities of soluble materials was improved.

- The Pitzer formulation (Pitzer 1981) for modeling situations where high ionic strengths prevail was added and verified.

- Conservation of water was built into the code to account for the mass of water contributed to the aqueous phase by the dissolution and precipitation of water-containing solid phases.

MINTEQ2 adopts the thermochemical data base of MINTEQ and is designed to accept an assemblage of gaseous and solid phases in contact with, but not necessarily in equilibriun with, an aqueous phase. The code then adjusts concentrations in the aqueous phase to conform to an equilibrium state between the gaseous, aqueous, and solid phases. Figure 2-1 outlines in simple block form the modeling capability of MINTEQ and the updated MINTEQ2 code. The analogy is a series of containers connected by vaives. The valves in the figure, (---o---), can be either open, indicating an open chemical system with respect to the solid and/or gas phases (infinite quantity), or closed, indicating a closed system (finite quantity). By opening or closing the valves between phases, it is possible to equilibrate only the aqueous phase, the aqueous and gas phases, the aqueous and mineral phases, the aqueous and adsorbed phases, or combinations of these.

To operate MINTEQ2, input is required on the total initial concentrations of all aqueous chemical elements, gas pressures, and, for certain applications, 


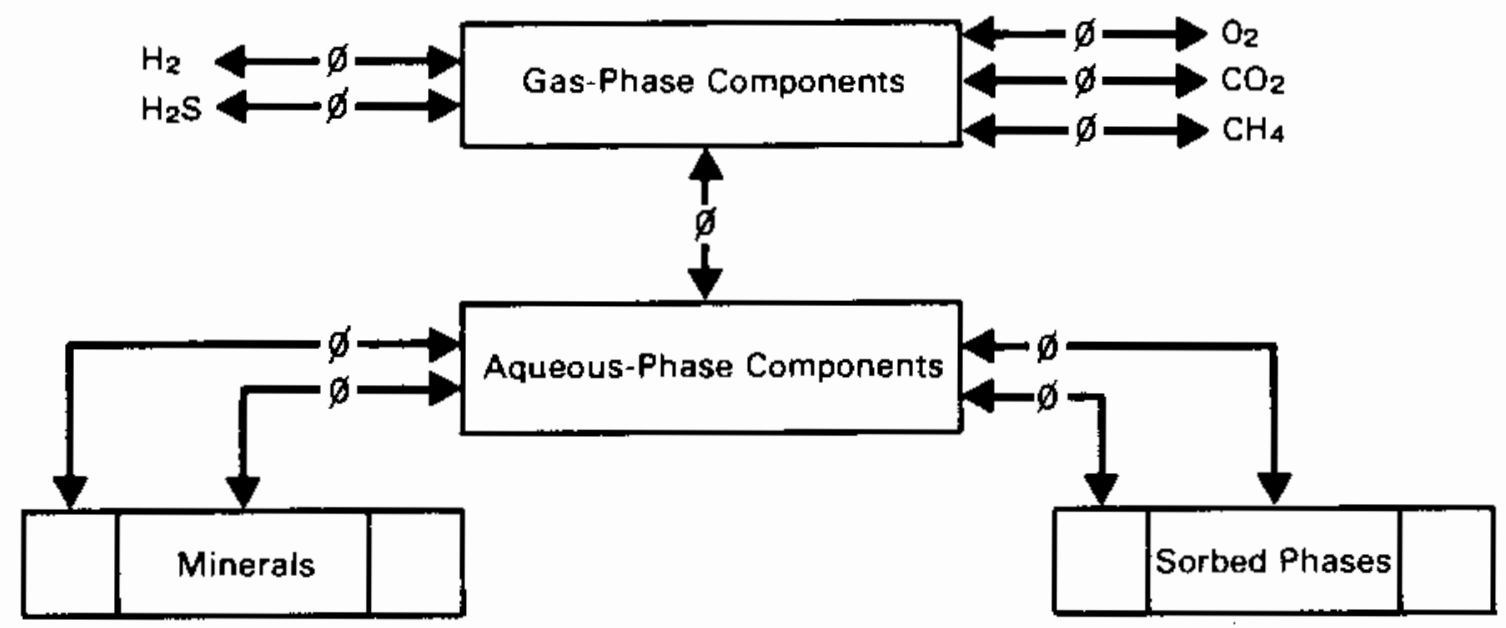

FIGURE 2.1. Schematic of Chemical Modeling Capabilities of MINTEQ2

identified solid phases. In addition, if adsorption is to be modeled, the adsorption algorithm is chosen and chemical equilibria describing the adsorption processes are added.

\subsection{THERMOCHEMICAL DATA BASE}

This report describes thermochemical data taken from the thermochemical data base associated with the chemical code GEOCHEM (Sposito and Mattigod 1980) reformatted into compatible form, and added to the already extensive thermochemical data base of the chemical equilibrium code, MINTEQ2. Adding these data will extend the capability of MINTEQ2 to model aqueous systems that contain certain organic ligands. Also, provisionary data for the aqueous species and solids of certain metals in the data base of GEOCHEM can be made available for some elements that have not yet been added to the MINTEQ2 data base. In particular, reactions for some elements (i.e., beryllium, cerium, cobalt, lanthanum, mercury, scandium, selenium, thorium, titanium, and tin), are available from the GEOCHEM data set, but are not yet publicly available in the thermochemical data bașe for MiNTEQ2.

\subsubsection{Previous Thermochemical Data Base}

Table 2.1 summarizes the contents of the thermochemical data base used by MINTEQ2 before the data from GEOCHEM were added. These data come in major part 
TABLE 2.1. Listing of Thermodynamic Data Base Before Additions

\begin{tabular}{|c|c|c|c|c|c|}
\hline $\begin{array}{c}\text { El ement } \\
\text { (Redox State) } \\
\end{array}$ & $\begin{array}{c}\text { Number of } \\
\text { Aqueous } \\
\text { Species }\end{array}$ & $\begin{array}{l}\text { Number of } \\
\text { Solid } \\
\text { Phases } \\
\end{array}$ & $\begin{array}{c}\text { El ement } \\
\text { (Redox State) } \\
\end{array}$ & $\begin{array}{c}\text { Number of } \\
\text { Aqueous } \\
\text { Species }\end{array}$ & $\begin{array}{c}\text { Number of } \\
\text { Solid } \\
\text { Phases }\end{array}$ \\
\hline $\mathrm{Ag}$ & 35 & 17 & Al & 11 & 46 \\
\hline As (III) & 5 & 5 & As $(V)$ & 4 & 10 \\
\hline B & 6 & 3 & $\mathrm{Ba}$ & 3 & 9 \\
\hline $\mathrm{Br}$ & 13 & 7 & $\mathrm{C}$ & 41 & 41 \\
\hline $\mathrm{Ca}$ & 10 & 52 & $\mathrm{Cd}$ & 34 & 23 \\
\hline $\mathrm{Cl}$ & 45 & 51 & $\operatorname{Cr}(\mathrm{III})$ & 31 & 11 \\
\hline $\operatorname{Cr}(V I)$ & 10 & 15 & Cs & 1 & 2 \\
\hline $\mathrm{Cu}(\mathrm{I})$ & 9 & 14 & $\mathrm{Cu}(\mathrm{II})$ & 20 & 31 \\
\hline F & 52 & 21 & $\mathrm{Fe}(\mathrm{II})$ & 10 & 22 \\
\hline $\mathrm{Fe}(\mathrm{III})$ & 23 & 27 & I & 13 & 11 \\
\hline k & 5 & 40 & $\mathrm{Li}$ & 2 & 1 \\
\hline $\mathrm{Mg}$ & 10 & 49 & $M_{n}(I I)$ & 13 & 11 \\
\hline $\operatorname{Mn}($ I I I ) & 1 & 6 & $M o(V I)$ & 10 & 23 \\
\hline$N($ II I $)$ & 10 & 3 & $N(I)$ & 2 & 0 \\
\hline$N(I V)^{\prime}$ & 13 & 6 & $\mathrm{Na}$ & 8 & 42 \\
\hline $\mathrm{Ni}$ & 15 & 10 & 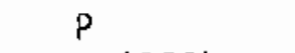 & 33 & 36 \\
\hline $\mathrm{Pb}$ & 28 & 46 & $\mathrm{Pu}(\mathrm{III})$ & $9(a)$ & $4(a)$ \\
\hline $\mathrm{Pu}(\mathrm{IV})$ & $17(a)$ & $5(a)$ & $\mathrm{Pu}(\mathrm{V})$ & 1 (a) & $i^{(a)}$ \\
\hline $\mathrm{Pu}(V \mathrm{I})$ & $8^{(a)}$ & $0^{(a)}$ & $\mathrm{Rb}$ & 1 & 1 \\
\hline$S(I I)$ & 54 & 28 & $S(V I)$ & 42 & 42 \\
\hline$S(I V)$ & 10 & 7 & SCN & 28 & 6 \\
\hline & 5 & 66 & & & \\
\hline TC (III) & 1 (a) & 0 (a) & $\mathrm{Tc}$ (IV) & 4 (a) & 0 (a) \\
\hline Tc (V) & $1(a)$ & $0^{(a)}$ & $T c(V I)$ & $3^{(a)}$ & 0 (a) \\
\hline TC(VII) & & $14^{(a)}$ & $U($ III) & $1^{(a)}$ & 2 (a) \\
\hline U(IV) & $19(a)$ & $34(a)$ & $U(V)$ & $2(a)$ & $5(a)$ \\
\hline U(VI) & $24(a)$ & $100^{(a)}$ & $V($ II $)$ & 2 & 0 \\
\hline$V($ III $)$ & 7 & 7 & $V(I V)$ & 9 & 8 \\
\hline$V(V)$ & 19 & 21 & $\mathrm{Zn}$ & 27 & 33 \\
\hline
\end{tabular}

(a) Enhancements and revisions currently being completed and documented.

from the WATEQ3 data base (Ball, Nordstrom and Jenne 1980; Ball Jenne and Cantrell 1980; Truesdell and Jones 1974) and later additions (Krupka and Jenne 1982). Though these available data have been extensively documented and evaluated and have been made internally consistent, it should be emphasized that not. a11 of these thermodynamical data still can be guaranteed correct. The selection of accurate and reliable thermochemical data is extremely important to the reliability of the chemical equilibrium calculations, and the efforts to achieve this goal should continue to be supported. 


\subsubsection{Need for Additions of Organic Ligands}

The migration of chemical elements in the soil, sediment, and rock depends on reactions that render the elements mobile in the aqueous phase. Certain polar organics are both soluble in water and good chelating agents. They may increase the dissolved concentrations of certain metals via the formation of chelated complexes. Some of these chelating agents may also lower concentrations of metals in the aqueous phase by causing the precipitation of organic solid phases. An example is the oxalate ligand that forms stable metal oxalate solids. Some of these organics originate in soils; others have been used in the chemical processes at Hanford.

Four organic 1 igands have been identified in Hanford waste tanks (Delegard, Barney and Gallagher 1983): 1) ethylenediaminetetraacetic acid (EDTA), 2) hydroxyacetate, 3) citrate, and 4) N-2-hydroxyethylendiaminetriacetate (HEDTA); only two of these are included in MINTEQ2. In addition, other organics used in the PUREX process for waste fractionization can also be expected to be present: 1) di(2-ethylhexyl)phosphate (DZEHPA), 2) tributyi phosphate (TBP), and 3) gluconates (ERDA 1977, P. A-3). Therefore, we anticipate that these additional ligands will need to be added to the MINTEQ2 data base.

\subsubsection{Source of Organic Thermochemical Data}

The organic data base assembled by Sposito and Mattigod (1980) contains a large number of reactions with organic ligands because it was designed to predict complex aqueous chemistry of soils high in organic matter. Because the soils at Hanford generally do not contain large amounts of organic matter, particularly below the surface, including all of these organics in the MINTEQ2 data base currentiy seems unwarranted. Therefore, at least for the time being, we have chosen to limit consideration to those ligands most closely related to organics found in the Hanford waste tanks themselves. Nevertheless, should other organics be needed, they can be readily extracted from the GEOCHEM data base by using the code, GEOMIN. 


\subsection{EXPANDED THERMODYAMIC OATA BASE}

The thermodynamical data added to MINTEQ2 all come from the data base released by Sposito and Mattigod (1980) to be used in their chemical code, GEOCHEM. They have gleaned data from a wide range of reputable sources (Martel) and Smith 1976, 77; Baes and Mesmer 1976; Robie, Hemingway and Fisher 1978; Sadiq and Lindsay 1979; Sposito 1977). Even though Sposito and Mattigod undoubtedly assembled these data with great care, the data cannot be guaranteed accurate nor internally consistent. The documentation for the GEDCHEM data base is not detailed enough to ensure that the proper procedure has been followed in each case in deriving the correct equilibrium constant. In most cases, of course, the data have been obtained from other sources. Most likely, some data have required manipulation to obtain an equilibrium constant, and so should be reviewed frequently and compared to new data on reactions of interest that appear in the chemical, geochemical, and soil chemical literature. It is very important to keep in mind that the calculational results can never be more accurate than the thermochemical data they contain.

Merging reactions from the GEOCHEM data base with reactions from the MINTEQ2 data base might also create internal inconsistencies. If reactions have been derived by combining other reactions, it is important that thermochemical data for the other reactions remain consistent throughout all the calculations. There is not enough documentary information to ensure that data from GEOCHEM will be internally consistent with those from MINTEQ2. If there are any discrepancies, they will have to be identified later in the program after it is determined which chemical elements and organic i igands are needed for the Hanford defense waste program.

The GEOCHEM data base does not contain separate enthalpies or entropies of reaction. Therefore, equilibrium constants from the source cannot be corrected for variation with respect to temperature. So in applying the data base to problems at different temperatures, it is implicitly assumed that the equilibrium constants for the additional organic complexes and solids are not temperature dependent. For certain reactions, this may be an untenable assumption. 


\subsection{ORGANIC LIGANDS IN THE SPOSITO-MATTIGDD DATA BASE (GEOCHEM)}

The GEOCHEM data base includes a large number of chemical reactions and equilibrium constants for organic chelates. Table 3.1 gives a full listing of the ligands avajlable in the GEOCHEM data base. The third column gives the index designation used by Sposito and Mattigod (1980); the fourth column is the index designation assigned for MINTEQ2 indices.

\subsection{GENERATION OF THE MINTEQ2-COMPATIBLE DATA BASE}

The GEOCHEM data base includes over 1700 reactions for organic and inorganic aqueous species and solids. The large number and the nondescriptive form of the entries for each reaction makes manual selection and reformatting difficult. In addition, a number of parameters needed for the MINTEQ2 data base are not included in the GEOCHEM data base. Consequent1y, a FORTRAN code called GEOMIN was written to select the data and calculate additional necessary parameters. Furthermore, including organic complexes and solids in the MINTEQ2 data base required the development of a protocol for unambiguously identifying them.

\subsubsection{Data Base Conversion}

GEOMIN is a FORTRAN code (see Appendix A for listing) that performs several functions in reading the GEOCHEM data base and converting the selected data to the format used in MINTEQ2:

- GEOMIN allows the user to select reactions to be retrieved, including metal species and ligands.

- GEOMIN calculates the charge on the species.

- GEOMIN separates aqueous complexation reactions from solubility reactions for minerals and related solids.

- GEOMIN assembles a MINTEQ2-compatible numerical index number for each reaction.

- GEOMIN assembles a name for the chemical species being formed by the reaction. 
IABLE 3.1. Organic Ligands included in the GEOCHEM Database

\begin{tabular}{|c|c|c|c|c|c|}
\hline Ligand & Species & $\frac{\text { Ind }}{\text { GEOCHEM }}$ & $\frac{\text { eX }}{\text { MINTEQ2 }}$ & Charge & $\begin{array}{l}\text { Formul a } \\
\text { We ight }\end{array}$ \\
\hline $\begin{array}{l}\text { Acetate } \\
\text { Acetylacetate } \\
\text { Citrate } \\
\text { Oxalate } \\
\text { Salicylate } \\
\text { Tartrate } \\
\text { Ethylenediamine } \\
\text { Dipyridyl } \\
\text { Sulfosalicylate } \\
\text { Glycine } \\
\text { Glutamate } \\
\text { Picolinate } \\
\text { Nitrotriacetate } \\
\text { Ethylenediaminetetraacetate } \\
\text { 1,2-diaminocyclohexane-tetraacetate } \\
\text { Cysteine } \\
\text { Nocardamine (desferri-ferrioxamine) } \\
\text { Phthalate } \\
\text { Arginine } \\
\text { Ornithine } \\
\text { Lysine } \\
\text { Hystidine } \\
\text { Aspartate } \\
\text { Serine } \\
\text { Alanine } \\
\text { Tyrosine } \\
\text { Methionine } \\
\text { Valine } \\
\text { Threonine } \\
\text { Phenylalanine } \\
\text { Isoleucine } \\
\text { Leucine } \\
\text { Proline } \\
\text { Diethylenetriamine-pentaacetate } \\
\text { Maleate } \\
\text { Benzylsulfonate } \\
\text { Formate } \\
\text { Fulvate I } \\
\text { Fulvate II } \\
\text { Ethylenedihydroxyphenylglycine } \\
\text { a }\end{array}$ & 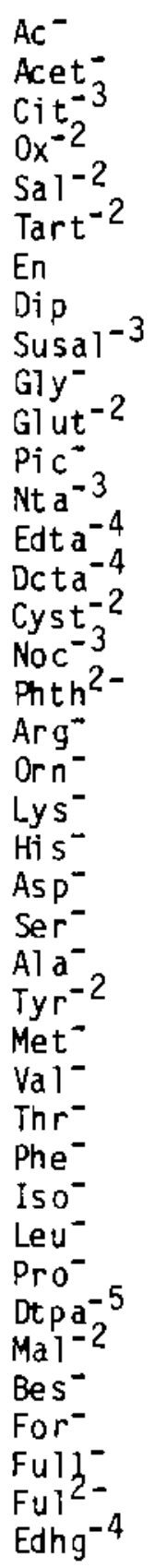 & $\begin{array}{l}15 \\
16 \\
17 \\
18 \\
19 \\
20 \\
21 \\
22 \\
23 \\
24 \\
25 \\
26 \\
27 \\
28 \\
29 \\
30 \\
31 \\
32 \\
33 \\
34 \\
35 \\
36 \\
37 \\
38 \\
39 \\
40 \\
41 \\
42 \\
43 \\
44 \\
45 \\
46 \\
47 \\
58 \\
60 \\
61 \\
65 \\
66 \\
67 \\
68\end{array}$ & $\begin{array}{l}\text { OV1 } \\
\text { OV3 } \\
\text { XV3 } \\
\text { VVO } \\
\text { RV1 } \\
\text { VV2 } \\
\text { ZZ2 } \\
\text { NR2 } \\
\text { RS1 } \\
\text { VZO } \\
\text { VZ3 } \\
\text { RW3 } \\
\text { NV3 } \\
\text { OVN } \\
\text { OV9 } \\
\text { SV2 } \\
\text { ZZO } \\
\text { RV2 } \\
\text { VZ7 } \\
\text { VZ4 } \\
\text { VZ6 } \\
\text { VZ7 } \\
\text { VZ8 } \\
\text { VZ1 } \\
\text { VZ2 } \\
\text { VZR } \\
\text { VZS } \\
\text { VZB } \\
\text { VZQ } \\
\text { VZT } \\
\text { VZD } \\
\text { VZC } \\
\text { NV4 } \\
\text { VN5 } \\
\text { VV2 } \\
125 \\
\text { VOD } \\
\text { OVY } \\
\text { OVZ } \\
\text { QZO }\end{array}$ & $\begin{array}{l}-1 \\
-1 \\
-3 \\
-2 \\
-2 \\
-2 \\
0 \\
0 \\
-3 \\
-1 \\
-2 \\
-1 \\
-3 \\
-4 \\
-4 \\
-2 \\
-3 \\
-2 \\
-1 \\
-1 \\
-1 \\
-1 \\
-1 \\
-1 \\
-1 \\
-2 \\
-1 \\
-1 \\
-1 \\
-1 \\
-1 \\
-1 \\
-1 \\
-5 \\
-2 \\
-1 \\
-1 \\
-1 \\
-1 \\
-4\end{array}$ & $\begin{array}{r}59.04 \\
117.08 \\
189.10 \\
88.02 \\
137.11 \\
148.07 \\
60.11 \\
156.19 \\
215.16 \\
74.06 \\
145.11 \\
228.09 \\
188.11 \\
281.21 \\
342.30 \\
153.13 \\
0.00 \\
164.12 \\
174.20 \\
131.15 \\
145.18 \\
154.15 \\
131.09 \\
104.08 \\
88.09 \\
179.17 \\
148.20 \\
116.14 \\
118.11 \\
164.18 \\
130.17 \\
130.17 \\
113.12 \\
390.32 \\
114.06 \\
157.17 \\
45.02 \\
450.00 \\
450.00 \\
246.20\end{array}$ \\
\hline
\end{tabular}


- GEOMIN generates a separate thermochemical data fite in MINTEQ2 format.

\subsubsection{Identification Indices for Organic Ligands}

The thermochemical data base for MINTEQ2 up to now has not included any organics except humic and fulvic acids. To expand the data base to include a larger number of organic ligands, it was necessary to devise a reasonable identification scheme for any organic-ligand reaction that would be added in the execution of this task. To satisfy this requirement, we chose a coding based on the Wiswesser Line-Formation notation (Smith 1968). This notation has been used for some time to unambiguously identify organic structures and is gaining more popularity with the use of computers (Baker, Palmer and Nichols 1975). It is a method for expressing the structure of an organic compound as a linear string of symbols. The resulting notation is compact, unique, unambigu.* ous, and particularly suitable for indexing and computer processing.

The scheme put forward in this document for naming the organics, though far from unambiguous, is at least consistent with the Wiswesser notation. It 1) provides an open-ended scheme for designating new organics and 2) provides some chemically specific descriptive information that could be searched in the data base. The coding is based on the Wiswesser Group Designations listed in Table 3.2.

These designations have been used to classify organics according to their two or three most important functional groups, listed according to their distance from the chelating or complexing group. When only two functional groups are specified, the third letter or number can be used as a sequence number or to designate the number of remaining non-hydrogen elements in the organic. As an example, consider ethylenediaminetetraacetate. The structure is

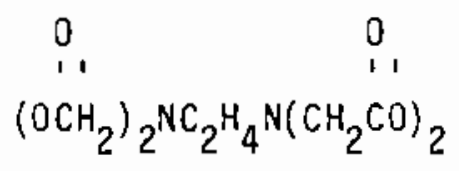




\section{TABLE 3.2. Wiswesser Group Designations}

Group

Letter Designation

Boron

Fluorine

lodine

Phosphorous

B

Sulfur

Carbonyl

Hydroxy

Chloro

Bromo

Carbon to 3 groups other than hydrogen

Carbon to 4 groups other than hydrogen

Hydrogen-free nitrogen attached to less than 4 others

Nitrogen attached to more than three other groups

$\mathrm{NH}_{2}$ group

-NA-group

Hydrogen-free oxygen, excluding $Q$ and $W$ cases

Ring system (such as benzene)

$B$
$F$
$I$
$P$
$S$
$V$
$Q$
$G$
$E$
$Y$
$X$
$N$
$K$
$Z$
$M$
$O$
$R$

Accordingly, the notation would be OVN, indicating that an oxygen, 0 , closest to the chelating position is attached to a carbonyl group, $V$, that is in turn attached to a hydrogen-free nitrogen, $N$.

Following these criteria, we have assigned designations as given in Table 3.3. In Table 3.3 lower case " $n$ " designates the number of carbons attached to the specific functional group. Thus ethyl alcohol would be Q2 (an $\mathrm{OH}$ group attached to two carbons) and acetone would be Vll (a carbonyl group attached to two separate methyl groups). 
TABLE 3.3. Designations for Organic Ligands

\begin{tabular}{|c|c|c|c|}
\hline Organic & Designation & Organic & Designation \\
\hline Acetal & OY & Acid anhydride & Vo or vov \\
\hline Acid Halide & $G V, E V$, et $c$. & Amino Acids & $V Z, M V, N V$, etc. \\
\hline Carboxylic acids & ovn & Al cohols & Qn \\
\hline Al dehydes & & Anides & $V Z, M$, or $V N$ \\
\hline Ureas & ZV, VM, or VN & Ргimary Amines & $\mathrm{Zn}$ \\
\hline Secondary Amines & & Tertiary Amines & Nn \\
\hline Esters & OVn & Ethers & \\
\hline Alkyl Halides & $\mathrm{Gn}$, En, et c. & Cycloalkyl talides & Gn, En, etc. \\
\hline $\begin{array}{l}\text { Aryl Halides } \\
\text { Ketones }\end{array}$ & GR, ER, etc. & Alkenes & Un \\
\hline $\begin{array}{l}\text { Ketones } \\
\text { Azoxy Comoounds }\end{array}$ & $V_{n n}$ & Azo Compounds & WN \\
\hline Azoxy Compounds & WN & Hydroazo Compounds & WN \\
\hline Isocyanates & NV & Isonitriles & Nn \\
\hline Nitriles & Nn & Nitro Compounds & $\mathrm{NW}$ \\
\hline Nitroso Compounds & NW & Phenols & RQ \\
\hline Thiocyanates & NS & Is othiochanates & SN \\
\hline Thio ethers & Sn & Thiols & SQ \\
\hline Thiophenois & RS & & \\
\hline
\end{tabular}

\subsection{OEFINITIONS AND THERMODYNAMIC STANDAROS}

The pressure-constant equilibrium constant for the reaction

$$
\mathrm{bB}+\mathrm{CC}+\ldots \longrightarrow \mathrm{P}
$$

is written as

$$
k_{r, T}=\left(a p / a^{0} p\right) /\left(\left(a_{B}^{b} / a^{o}{ }_{B}^{b}\right)\left(a_{C} c / a^{o} c c\right) \ldots\right)
$$

where $K_{r, T}=$ the equilibrium constant for reaction $r$ at temperature $T$ $a_{j}=$ the activity of the product $(j=P)$, or reactant $(j=A, B)$ species; the activity is in turn expressed as the product of an activity coefficient and a concentration for that species $a^{0}{ }_{j}=$ the activity of the $j$ th species at standard state; this quantity is generally defined as unity (e.g., unit molality) $a, b=$ stoichiometric coefficients for the reaction. 
When defined in this way, $K r, T$ will always be dimensionless so that it will relate correctly to the thermodynamic quantity,

$$
\Delta G_{C r, T}^{0}=R \Pi n K_{r, T}=\Delta H_{r, T}^{0}-T \Delta S_{r, T}^{0}
$$

where $\Delta G^{0}{ }_{r, T}$ is the standard Gibbs free energy of reaction, $R$ is the gas constant, $T$ is the absolute temperature, $\Delta H^{0}{ }_{r, T}$ is the standard enthalpy of reaction, and $\Delta S^{0}{ }_{r, T}$ is the standard entropy of reaction. Usually, the standard state is taken to be unity. Therefore the equilibrium constant, $K_{r, T}$ is more frequently written as

$$
k_{r, T}=a p /\left(a_{B}{ }^{b}{ }_{C}{ }^{c} \ldots\right)
$$

According to Sposito and Mattigod (1980), the thermochemical data presented in their report are based on a standard state of moles per liter (molar). The units of the MINTEQ2 thermochemical data base are based on a more fundamentally useful concentration unit when the temperature is to be varied or when concentrations range widely [i.e., moles/1000 g of water (molal)]. However, for dilute solutions, the two standard states are equivalent to an adequate degree of approximation. Thus, if the equilibrium constant is obtained at sufficientiy dilute concentration, or is extrapolated accurately to dilute concentration, the units for the two data bases will be consistent.

\subsection{SELECTED ORGANIC LIGANDS}

Tables 3.4 through 3.10 summarize the selected reactions and their equilibrium constants. The first column in each table given a unique identification code for the reaction. The second column gives the base-ten logarithm of the equilibrium constant for the reaction at $25^{\circ} \mathrm{C}$ and 1.0 atmosphere pressure. The third column gives the name of the product that has been generated by GEOMIN by concatenating names and charges of the reactants. The fourth 
column defines the reaction. Reaction coefficients are positive if the component is a reactant and negative if the component is a product. For example, the reaction

$$
281 \times \text { V } 37-6.56 \mathrm{Fe}_{2}(\mathrm{Cit})_{2}(\mathrm{OH})_{2}^{-2}(\mathrm{Aq})+\mathrm{Fe}^{+3}+2 \mathrm{Cit}^{-3}+2 \mathrm{H}_{2} \mathrm{O}-2 \mathrm{H}^{+}
$$

should be interpreted to conventionally read

$$
2 \mathrm{Fe}^{+3}+2 \mathrm{Cit}^{-3}+2 \mathrm{H}_{2} \mathrm{O}+\mathrm{Fe}_{2}(\mathrm{Cit})_{2}(\mathrm{OH})_{2}^{-2}(\mathrm{Aq})+2 \mathrm{H}^{+}, \log \mathrm{K}=-6.56
$$

The designation ( $\mathrm{Aq}$ ) indicates that the product is aqueous and (So) indicates that the product is solid.

The following tables list all reactions added from the GEOCHEM data base that invoive designated ligands.

\subsubsection{Acetates}

\begin{tabular}{|c|c|c|c|c|c|c|}
\hline ID & $\log \left(K^{0}, T\right)$ & Product & \multicolumn{4}{|c|}{ Reaction } \\
\hline $1500 \vee 14$ & 1.20 & $\overline{C a}(A C)^{+1}$ & $(A q)$ & $+\mathrm{Ca}^{+2}$ & + & $A C^{-}$ \\
\hline $4600 V 14$ & 1.30 & $\operatorname{Mg}(A C)^{+1}$ & $(A q)$ & $+\mathrm{Mg}^{+2}$ & + & $\mathrm{AC}^{-}$ \\
\hline 8000 V 14 & 0.90 & $\operatorname{Sr}(A C)^{+1}$ & $(A q)$ & $+5 r+2$ & + & $\mathrm{AC}^{-}$ \\
\hline $5000 \vee 14$ & -0.20 & $\mathrm{Na}(\mathrm{AC})$ & $(A q)$ & $+\mathrm{Na}^{+}$ & + & $\mathrm{Ac}^{-}$ \\
\hline $2810 \vee 14$ & 4.20 & $\mathrm{Fe}(A C)^{+2}$ & $(A q)$ & $+\mathrm{Fe}^{+3}$ & + & $\mathrm{Ac}^{-}$ \\
\hline $2810 \vee 15$ & 7.50 & $\mathrm{Fe}(\mathrm{AC})_{2}^{+1}$ & $(A q)$ & $+\mathrm{Fe}^{+3}$ & +2 & $\mathrm{Ac}^{-}$ \\
\hline $2810 \vee 16$ & 10.50 & $\mathrm{Fe}(\mathrm{AC})_{3}$ & $(A q)$ & $\leftarrow \mathrm{Fe}^{+3}$ & +3 & $\mathrm{AC}^{-}$ \\
\hline $2800 V 14$ & 1.40 & $\mathrm{Fe}(A C)^{+1}$ & $(A q)$ & $\leftarrow \mathrm{Fe}^{+2}$ & + & $\mathrm{AC}^{-}$ \\
\hline $4700 \vee 14$ & 1.40 & $\operatorname{Mn}(A C)^{+1}$ & $(A q)$ & $\leftarrow \mathrm{Mn}^{+2}$ & & $A C^{-}$ \\
\hline $4700 \vee 15$ & 2.20 & $M n(A C)_{2}$ & $\langle A q\rangle$ & $+M n^{+2}$ & +2 & $\mathrm{Ac}^{-}$ \\
\hline 2310 V14 & 2.20 & $\mathrm{Cu}(\mathrm{AC})^{+1}$ & $(A q)$ & $+\mathrm{Cu}^{+2}$ & & $\mathrm{AC}^{-}$ \\
\hline $2310 \vee 15$ & 3.50 & $\mathrm{Cu}(\mathrm{AC})_{2}$ & $(A q)$ & $+\mathrm{Cu}^{+2}$ & +2 & $A C^{-}$ \\
\hline
\end{tabular}

TABLE 3.4. Thermochemical Additions for Acetates 
TABLE 3.4. (Contd)

\begin{tabular}{|c|c|c|c|c|c|}
\hline ID & $\log \left(K_{r, T}^{0}\right)$ & Product & \multicolumn{3}{|c|}{ Reaction } \\
\hline $2310 \vee 16$ & 3.90 & $\mathrm{Cu}(\mathrm{AC}) \mathrm{3}^{-1}$ & $(\mathrm{Aq})$ & $+\mathrm{Cu}^{+2}$ & $+3 \mathrm{AC}^{-}$ \\
\hline $2310 \mathrm{~V} 17$ & 3.40 & $\mathrm{Cu}(\mathrm{AC})_{4}^{-2}$ & $(A q)$ & $+\mathrm{Cu}^{+2}$ & $+4 \mathrm{Ac}^{-}$ \\
\hline $1000 \mathrm{~V} 14$ & 0.90 & $\mathrm{Ba}(\mathrm{AC})^{+1}$ & $(\mathrm{Aq})$ & $+\mathrm{Ba}^{+2}$ & $+\mathrm{AC}^{-}$ \\
\hline $1600 \vee 14$ & 2.60 & $C d(A C)^{+1}$ & $(\mathrm{Aq})$ & $+\mathrm{Cd}^{+2}$ & $+\mathrm{AC}^{-}$ \\
\hline $1600 \vee 15$ & 3.60 & $\mathrm{Cd}(\mathrm{AC})_{2}$ & $(\mathrm{Aq})$ & $+\mathrm{Cd}^{+2}$ & $+2 \mathrm{AC}^{-}$ \\
\hline $1600 v 16$ & 4.20 & $\operatorname{Cd}(A C)_{3}^{-1}$ & $(A q)$ & $+\mathrm{Cd}^{+2}$ & $+3 \mathrm{AC}^{-}$ \\
\hline $1600 \vee 17$ & 1.80 & $\mathrm{Cd}(A C)_{4}^{-2}$ & $(\mathrm{Aq})$ & $+\mathrm{Cd}^{+2}$ & $+4 \mathrm{AC}^{-}$ \\
\hline $9500 \mathrm{~V} 14$ & 1.80 & $\ln (A C)^{+1}$ & $(A q)$ & $+Z n^{+2}$ & $+\mathrm{AC}^{-}$ \\
\hline $9500 \vee 15$ & 2.90 & $\operatorname{Zn}(A C)_{2}$ & $(\mathrm{Aq})$ & $+2 n^{+2}$ & $+2 \mathrm{AC}^{-}$ \\
\hline $5400 \vee 14$ & 1.20 & $\mathrm{Ni}(A C)^{+1}$ & $(A q)$ & $+\mathrm{Ni}^{+2}$ & $+\mathrm{AC}^{-}$ \\
\hline $5400 \vee 15$ & 2.10 & $\mathrm{Ni}(A C)_{2}$ & $(A q)$ & $+\mathrm{Ni}^{+2}$ & $+2 \mathrm{AC}^{-}$ \\
\hline $6000 \vee 14$ & 2.40 & $P b(A C)^{+1}$ & $(A q)$ & $+\mathrm{Pb}^{+2}$ & $+\mathrm{AC}^{-}$ \\
\hline $6000 \vee 15$ & 4.10 & $\mathrm{~Pb}(A C)_{2}$ & $(\mathrm{Aq})$ & $+\mathrm{Pb}^{+2}$ & $+2 \mathrm{AC}^{-}$ \\
\hline $2000 V 14$ & 1.60 & $\operatorname{Co}(A C)^{+1}$ & $(A q)$ & $+\mathrm{CO}^{+2}$ & $+\mathrm{AC}^{-}$ \\
\hline $2000 \vee 15$ & 2.40 & $\mathrm{Co}(\mathrm{AC})_{2}$ & $(\mathrm{Aq})$ & $+\mathrm{Co}^{+2}$ & $+2 A C^{-}$ \\
\hline 9002001 & 2.30 & $\mathrm{Ag}(\mathrm{Ac})$ & (So) & $+\mathrm{Ag}^{+}$ & $+\mathrm{AC}^{-}$ \\
\hline $0200 \vee 14$ & 0.60 & $\mathrm{Ag}(\mathrm{Ac})$ & $(\mathrm{Aq})$ & $+\mathrm{Ag}^{+}$ & $A C^{-}$ \\
\hline $0300 \vee 14$ & 2.10 & $A l(A C)^{+2}$ & $(A q)$ & $+\mathrm{Al}^{+3}$ & $\mathrm{AC}^{-}$ \\
\hline $4400 \vee 14$ & 0.20 & $L i(A C)$ & $(\mathrm{Aq})$ & $+\mathrm{Li}^{+}$ & $\mathrm{AC}^{-}$ \\
\hline $4300 \vee 14$ & 2.90 & $\mathrm{La}(\mathrm{AC})^{+2}$ & $(A q)$ & $+\mathrm{lag}^{+3}$ & $+\mathrm{AC}^{-}$ \\
\hline $4300 \vee 15$ & 4.80 & $\operatorname{La}(A C)_{2}^{+1}$ & $(\mathrm{Aq})$ & $+\mathrm{La}^{+3}$ & $+2 \mathrm{AC}^{-}$ \\
\hline $1700 \vee 14$ & 3.00 & $\mathrm{Ce}(\mathrm{AC})^{+2}$ & $(\mathrm{Aq})$ & $+\mathrm{Ce}^{+3}$ & $+A C^{-}$ \\
\hline $1700 \mathrm{~V} 15$ & 5.00 & $\mathrm{Ce}(\mathrm{Ac})_{2}^{+1}$ & $(\mathrm{Aq})$ & $+\mathrm{Ce}^{+3}$ & $+2 \mathrm{AC}^{-}$ \\
\hline $8930 \vee 14$ & 3.00 & $\mathrm{UO}_{2}(\mathrm{AC})^{+1}$ & $(\mathrm{Aq})$ & $+\mathrm{UO}_{2}+2$ & $+\mathrm{Ac}^{-}$ \\
\hline $8930 \vee 15$ & 5.30 & $\mathrm{UO}_{2}(\mathrm{AC})_{2}$ & (Aq) & & $+2 \mathrm{AC}^{-}$ \\
\hline $8930 \vee 16$ & 7.20 & $\mathrm{UO}_{2}(\mathrm{AC})_{3}^{-1}$ & $(\mathrm{Aq})$ & $+\mathrm{UO}_{2}+2$ & $+3 \mathrm{AC}^{-}$ \\
\hline $3300 \vee 14$ & 4.80 & $(A C) H$ & $(\mathrm{Aq})$ & $+\mathrm{AC}^{-}$ & $+\mathrm{H}^{+}$ \\
\hline
\end{tabular}




\subsubsection{Citrates}

TABLE 3.5. Thermochemical Additions for Citrates

\begin{tabular}{|c|c|c|c|c|}
\hline ID & $\log \left(K_{r, T}^{0}\right)$ & Product & & Reaction \\
\hline $150 \times v 34$ & 4.70 & $\mathrm{Ca}(\mathrm{Cit})^{-1}$ & $(\mathrm{Aq})+\mathrm{Ca}^{+2}$ & $+\mathrm{Cit}^{-3}$ \\
\hline $150 \times v 35$ & 9.50 & $\mathrm{Ca}(\mathrm{Cit}) \mathrm{H}$ & $(\mathrm{Aq})+\mathrm{Ca}^{+2}$ & $+\mathrm{Cit}^{-3}+\mathrm{H}^{+}$ \\
\hline $150 \times \vee 36$ & 12.30 & $\mathrm{Ca}(\mathrm{Cit}) \mathrm{H}_{2}^{+1}$ & $(\mathrm{Aq})+\mathrm{Ca}^{+2}$ & $\mathrm{Cit}^{-3}+2 \mathrm{H}^{+}$ \\
\hline $460 \times \vee 34$ & 3.40 & $\mathrm{Mg}(\mathrm{Cit})^{-1}$ & $(\mathrm{Aq})+\mathrm{Mg}^{+2}$ & $+\mathrm{Cit}^{-3}$ \\
\hline $460 \times \vee 35$ & 8.20 & $\mathrm{Mg}(\mathrm{Cit}) \mathrm{H}$ & $(A q)+M g+2$ & $\mathrm{Cit}^{-3}+\mathrm{H}^{+}$ \\
\hline $460 \times v 36$ & 12.00 & $\mathrm{Mg}(\mathrm{Cit}) \mathrm{H}_{2}^{+1}$ & $(\mathrm{Aq})+\mathrm{Mg}+2$ & $\mathrm{Cit}^{-3}+2 \mathrm{H}^{+}$ \\
\hline $800 \times \vee 34$ & 4.10 & $\operatorname{Sr}(C i t)^{-1}$ & $(A q)+S r+2$ & $+\mathrm{Cit}^{-3}$ \\
\hline $800 \times v 35$ & 20.80 & $\mathrm{Sr}(\mathrm{Cit}) \mathrm{H}$ & $(\mathrm{Aq})+\mathrm{Sr}^{+2}$ & $\mathrm{Cit}^{-3}+\mathrm{H}^{+}$ \\
\hline $410 \times v 34$ & 1.20 & $K(\mathrm{Cit})^{-2}$ & $(A q)+K^{+}$ & $+\mathrm{Cit}^{-3}$ \\
\hline $500 \times \vee 34$ & 1.40 & $\mathrm{Na}(\mathrm{Cit})^{-2}$ & $(\mathrm{Aq})+\mathrm{Na}^{+}$ & $+\mathrm{Cit}^{-3}$ \\
\hline $281 \times \vee 34$ & 11.50 & $\mathrm{Fe}(\mathrm{Cit})$ & $(A q)+F e^{+3}$ & $\mathrm{Cit}^{-3}$ \\
\hline $281 \times \vee 35$ & 29.50 & $\mathrm{Fe}(\mathrm{Cit}) \mathrm{H}^{+1}$ & $(A q)+\mathrm{Fe}^{+3}$ & $\mathrm{Cit}^{-3}+\mathrm{H}^{+}$ \\
\hline $281 \times \vee 36$ & 30.40 & $\mathrm{Fe}(\mathrm{Cit}) \mathrm{H}_{2}^{+2}$ & $(A q)+F e^{+3}$ & $+\mathrm{Cit}^{-3}+2 \mathrm{H}^{+}$ \\
\hline $281 \times \vee 37$ & 21.40 & $\mathrm{Fe}_{2}(\mathrm{Cit})_{2}(\mathrm{OH})_{2}^{-2}$ & $(\mathrm{Aq})+2 \mathrm{Fe}^{+3}$ & $+2 \mathrm{Cit}^{-3}+2 \mathrm{H}_{2} \mathrm{O}-2 \mathrm{H}^{+}$ \\
\hline $280 \times \vee 34$ & 4.40 & $\mathrm{Fe}(\mathrm{Cit})^{-1}$ & $(A q)+F e^{+2}$ & $+\mathrm{Cit}^{-3}$ \\
\hline $280 \times v 35$ & 9.00 & $\mathrm{Fe}(\mathrm{Cit}) \mathrm{H}$ & $(\mathrm{Aq})+\mathrm{Fe}^{+2}$ & $\mathrm{Cit}^{-3}+\mathrm{H}^{+}$ \\
\hline $470 \times \vee 34$ & 5.40 & $\operatorname{Mn}(\mathrm{Cit})^{-1}$ & $(A q)+M n+2$ & $\mathrm{Cit}^{-3}$ \\
\hline $470 \times v 35$ & 9.60 & $\mathrm{Mn}(\mathrm{Cit}) \mathrm{H}$ & $(A q)+M n+2$ & $\mathrm{Cit}^{-3}+\mathrm{H}^{+}$ \\
\hline $231 \times \vee 34$ & 5.90 & $\mathrm{Cu}(\mathrm{Cjt})-1$ & $(A q)+C u+2$ & Cit-3 \\
\hline $231 \times \vee 35$ & 9.80 & $\mathrm{Cu}(\mathrm{Cit}) \mathrm{H}$ & $(\mathrm{Aq})+\mathrm{Cu}^{+2}$ & $\mathrm{Cit}^{-3}+\mathrm{H}^{+}$ \\
\hline $231 \times \vee 36$ & 13.40 & $\mathrm{Cu}(\mathrm{Cit}) \mathrm{H}_{2}^{+1}$ & $(\mathrm{Aq})+\mathrm{Cu}^{+2}$ & $\mathrm{Cit}^{-3}+2 \mathrm{H}^{+}$ \\
\hline $231 \times v 37$ & -15.58 & $\mathrm{Cu}(\mathrm{Cit})(\mathrm{OH})^{-2}$ & $(A q)+\mathrm{Cu}^{+2}$ & $\mathrm{Cit}^{-3}+\mathrm{H}_{2} \mathrm{O}-\mathrm{H}^{+}$ \\
\hline $231 \times \vee 38$ & 8.10 & $\mathrm{Cu}_{2}(\mathrm{Cit})^{+1}$ & $(\mathrm{Aq})+2 \mathrm{Cu}^{+2}$ & $\mathrm{Cit}^{-3}$ \\
\hline $100 \times v 34$ & 2.90 & $\mathrm{Ba}(\mathrm{Cit})^{-1}$ & $(A q)+B a^{+2}$ & $\mathrm{Cit}^{-3}$ \\
\hline $100 \times v 35$ & 8.20 & $\mathrm{Ba}(\mathrm{Cit}) \mathrm{H}$ & $(A q)+B a^{+2}$ & $\mathrm{Cit}^{-3}+\mathrm{H}^{+}$ \\
\hline $100 \times 136$ & 11.90 & $\mathrm{Ba}(\mathrm{Cit}) \mathrm{H}_{2}^{+1}$ & $(\mathrm{Aq})+\mathrm{Ba}^{+2}$ & $\mathrm{Cit}^{-3}+2 \mathrm{H}^{+}$ \\
\hline $160 \times \vee 34$ & 3.80 & $\mathrm{Cd}(\mathrm{Cit})^{-\overline{1}}$ & $(\mathrm{Aq})+\mathrm{Cd}^{+2}$ & $+\mathrm{Cit}^{-3}$ \\
\hline $160 \times \vee 35$ & 5.40 & $\mathrm{Cd}(\mathrm{Cit})_{2}^{-4}$ & $(\mathrm{Aq})+\mathrm{Cd}^{+2}$ & $+2 \mathrm{Cit}^{-3}$ \\
\hline $160 \times \vee 36$ & 8.60 & $\mathrm{Cd}(\mathrm{Cit}) \mathrm{H}$ & $(\mathrm{Aq})+\mathrm{Cd}^{+2}$ & $+\mathrm{Cit}^{-3}+\mathrm{H}^{+}$ \\
\hline $160 \times v 37$ & 12.10 & $\mathrm{Cd}(\mathrm{Cit}) \mathrm{H}_{2}^{+1}$ & $(\mathrm{Aq})+\mathrm{Cd}^{+2}$ & $\mathrm{Cit}^{-3}+2 \mathrm{H}^{+}$ \\
\hline
\end{tabular}


TABLE 3.5. (Contd)

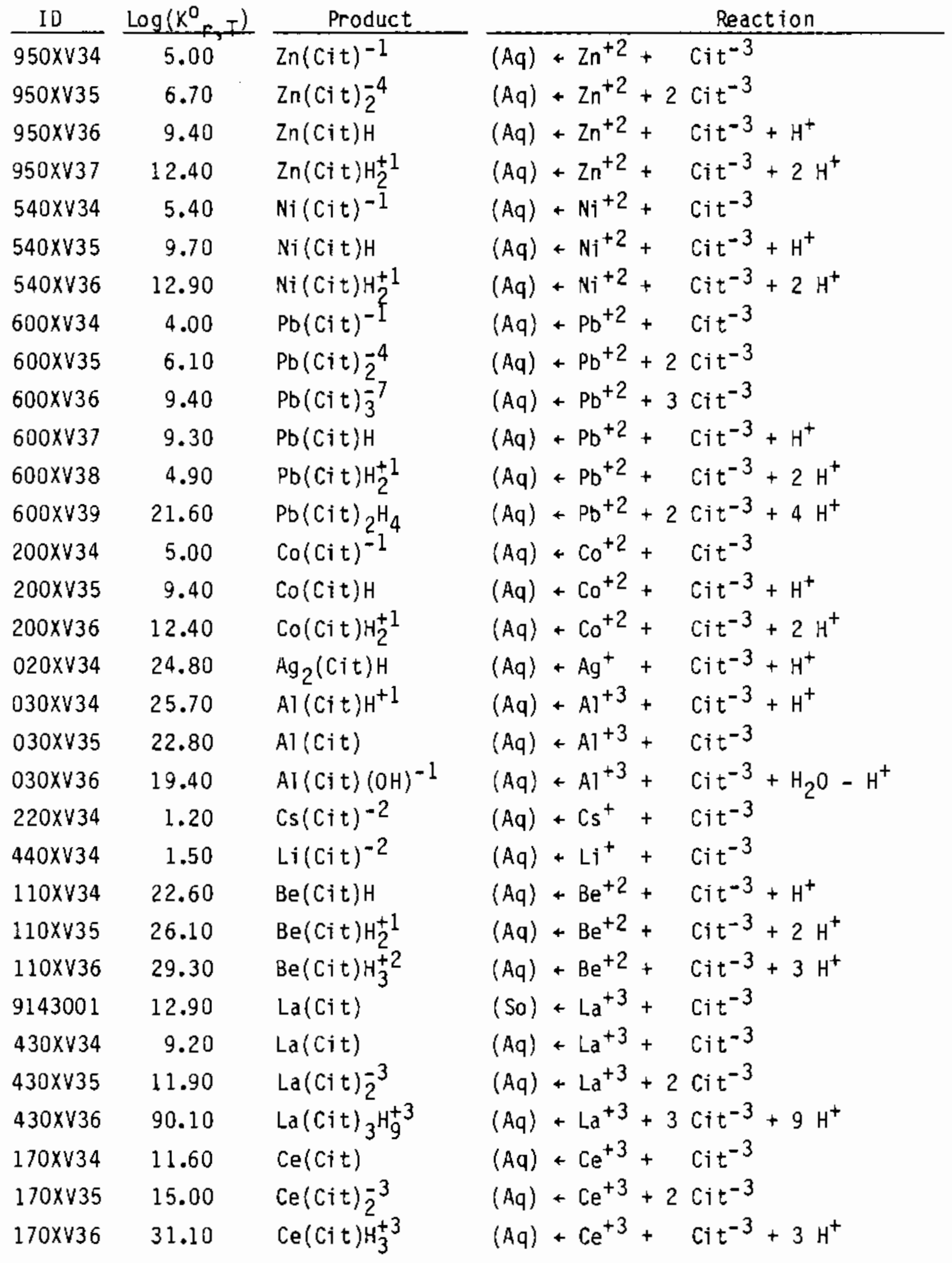


TABLE 3.5. (Contd)

\begin{tabular}{|c|c|c|c|c|c|}
\hline 10 & $\log \left(K^{0}, T\right)$ & Product & Rear & ction & \\
\hline $850 \times \vee 34$ & 16.80 & $\operatorname{Th}(\mathrm{Cit})^{+1}$ & $(\mathrm{Aq})+\mathrm{Th}^{+4}$ & $+\mathrm{Cit}^{-3}$ & \\
\hline $850 \times \vee 35$ & 25.70 & $\operatorname{Th}(\mathrm{Cit})^{-2}$ & $(\mathrm{Aq}) \div \mathrm{Th}^{+4}$ & $+2 \mathrm{Cit}^{-3}$ & \\
\hline $893 \times \vee 34$ & 9.30 & $\mathrm{UO}_{2}(\mathrm{Cit})^{-1}$ & $(A q)+U 0_{2}^{+2}$ & $+\mathrm{Cit}^{-3}$ & \\
\hline $893 \times \vee 35$ & 26.60 & $\mathrm{UO}_{2}(\mathrm{Cit}) \mathrm{H}$ & $(A q)+U 0_{2}^{+2}$ & $\mathrm{Cit}^{-3}$ & $+\mathrm{H}^{+}$ \\
\hline $680 \times \vee 34$ & 1.10 & $\mathrm{Rb}(\mathrm{Cit})^{-2}$ & $(A q)+R b^{+}$ & $\mathrm{Cit}^{-3}$ & \\
\hline $330 \times v 34$ & 6.40 & $(\mathrm{Cit}) \mathrm{H}^{-2}$ & $(\mathrm{Aq})+\mathrm{Cit}^{-3}$ & $+\mathrm{H}^{+}$ & \\
\hline $330 \times \vee 35$ & 11.20 & $(\mathrm{Cit}) \mathrm{H}_{2}^{-1}$ & $(\mathrm{Aq})+\mathrm{Cit}^{-3}$ & $+2 \mathrm{H}^{+}$ & \\
\hline $330 \times \vee 36$ & 14.30 & $(\mathrm{Cit}) \mathrm{H}_{3}$ & $(\mathrm{Aq})+\mathrm{Cit}^{-3}$ & $+3 \mathrm{H}^{+}$ & \\
\hline
\end{tabular}

\subsubsection{0iethylenetriaminepentaacetates}

TABLE 3.6. Thermochemical Additions for Diethyl enetriaminepentaacetates

\begin{tabular}{|c|c|c|c|}
\hline 10 & $\log (K)$ & Product & Reaction \\
\hline 150VN54 & 10.80 & $\mathrm{Ca}(\mathrm{Dtpa})^{-3}$ & $(\mathrm{Aq})+\mathrm{Ca}^{+2}+\mathrm{Dt} \mathrm{pa}^{-5}$ \\
\hline 150VN55 & 16.90 & $\mathrm{Ca}(\mathrm{Dtpa}) \mathrm{H}^{-2}$ & $(\mathrm{Aq})+\mathrm{Ca}^{+2}+\mathrm{Dtpa}^{-5}+\mathrm{H}^{+}$ \\
\hline 150VN56 & 12.80 & $\mathrm{Ca} 2(\mathrm{Dtpa})^{-1}$ & $(\mathrm{Aq})+2 \mathrm{Ca}^{+2}+\mathrm{Dtpa}^{-5}$ \\
\hline $460 \vee$ N54 & 9.30 & $M g(D t p a)^{-3}$ & $(\mathrm{Aq})+\mathrm{Mg}^{+2}+D t p \mathrm{a}^{-5}$ \\
\hline $460 V N 55$ & 16.40 & $\mathrm{Mg}(\mathrm{Dtpa}) \mathrm{H}^{-2}$ & $\mathrm{Mg}^{+2}+\mathrm{Dtpa}^{-5}+\mathrm{H}^{+}$ \\
\hline $800 \vee N 54$ & 11.90 & $\operatorname{Sr}(D t p a)^{-3}$ & $S r^{+2}+D t p a^{-5}$ \\
\hline 281 VN54 & 28.00 & $\mathrm{Fe}(\mathrm{Dtpa})^{-2}$ & $\mathrm{Fe}^{+3}+\mathrm{Dtpa}^{-5}$ \\
\hline 281 VN55 & 31.60 & $\mathrm{Fe}(\mathrm{Dtpa}) \mathrm{H}^{-1}$ & $\mathrm{Fe}^{+3}+\mathrm{Otpa}^{-5}+\mathrm{H}^{+}$ \\
\hline $281 V N 56$ & 31.90 & $\mathrm{Fe}(\mathrm{Dt} \mathrm{Pa})(\mathrm{OH})^{-3}$ & $\mathrm{Fe}^{+3}+\mathrm{DtPa}^{-5}+\mathrm{H}_{2} \mathrm{O}-\mathrm{H}^{+}$ \\
\hline $280 \vee N 54$ & 16.50 & $\mathrm{Fe}(\mathrm{Dt} p \mathrm{a})^{-3}$ & $\mathrm{Fe}^{+2}+\mathrm{Dtpa}^{-5}$ \\
\hline 280VN55 & 21.90 & $\mathrm{Fe}(\mathrm{Dt} \mathrm{pa}) \mathrm{H}^{-2}$ & $\mathrm{Fe}^{+2}+\mathrm{Dtpa}^{-5}+\mathrm{H}^{+}$ \\
\hline 2B0VN56 & 22.70 & $\mathrm{Fe}(\mathrm{Dtpa})(\mathrm{OH})^{-4}$ & $\mathrm{Fe}^{+2}+\mathrm{Dtpa}^{-5}+\mathrm{H}_{2} \mathrm{O}-\mathrm{H}^{+}$ \\
\hline 280 VN57 & 26.00 & $\mathrm{Fe}(\mathrm{DtPa})(\mathrm{OH})_{2}^{-5}$ & $\mathrm{Fe}^{+2}+\mathrm{Dtpa}^{-5}+2 \mathrm{H}_{2} \mathrm{O}-2 \mathrm{H}^{+}$ \\
\hline 470 VN54 & 15.60 & $\operatorname{Mn}(D t p a)^{-3}$ & $\mathrm{Mn}^{+2}+\mathrm{Dtpa}_{\mathrm{p}}^{-5}$ \\
\hline 470 VN55 & 20.20 & $\operatorname{Mn}(D t p a) H^{-2}$ & $(\mathrm{Aq})+\mathrm{Mn}^{+2}+\mathrm{Dtpa}^{-5}+\mathrm{H}^{+}$ \\
\hline 470 VN5 6 & 17.70 & $\operatorname{Mn} 2(D t p a)^{-1}$ & $(A q)+2 \mathrm{Mn}^{+2}+D t p a^{-5}$ \\
\hline 231 VN54 & 21.60 & $\mathrm{Cu}(\mathrm{Dtpa})^{-3}$ & $(\mathrm{Aq})+\mathrm{Cu}^{+2}+\mathrm{Dt} \mathrm{pa}^{-5}$ \\
\hline 231VN55 & 26.30 & $\mathrm{Cu}(\mathrm{Dtpa}) \mathrm{H}^{-2}$ & $(\mathrm{Aq})+\mathrm{Cu}^{+2}+\mathrm{Dtpa}^{-5}+\mathrm{H}^{+}$ \\
\hline
\end{tabular}


TABLE 3.6. (Contd)

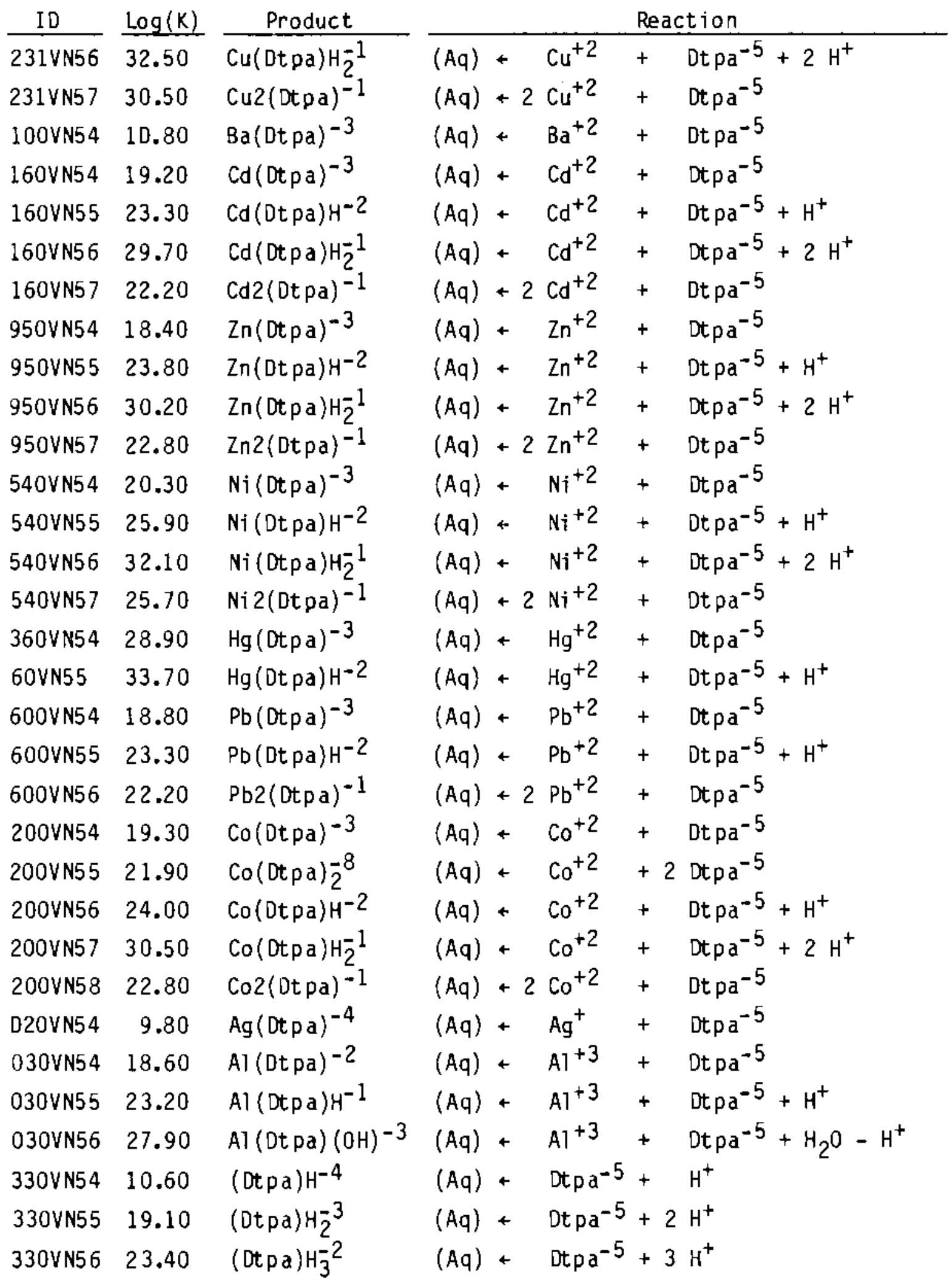




\subsubsection{Ethylenediamines}

TABLE 3.7. Thermochemical Additions for Ethylenediamines

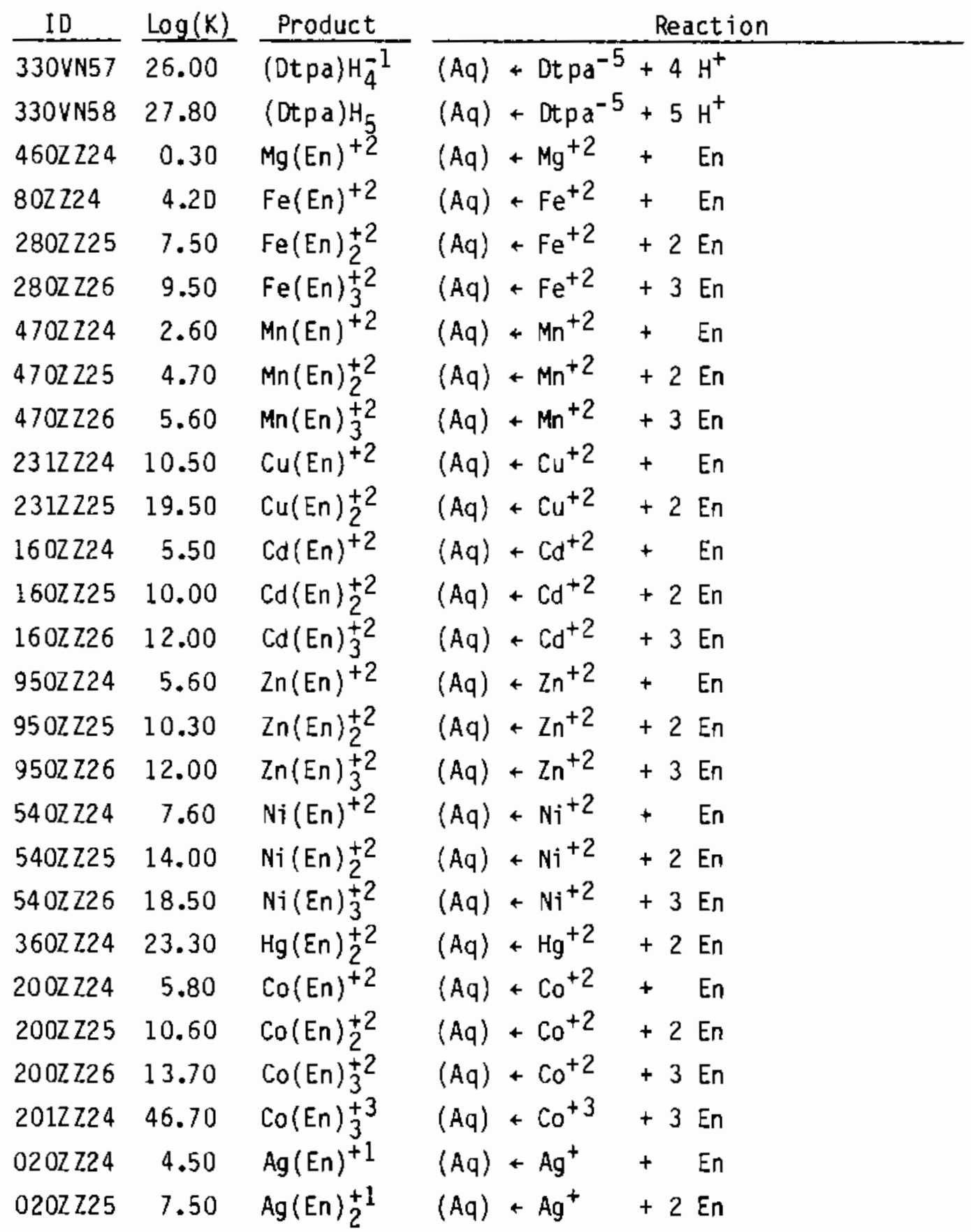


TABLE 3.7. (Contd)

\begin{tabular}{|c|c|c|c|}
\hline ID & $\log (K)$ & Product & Reaction \\
\hline 2302224 & 10.80 & $\mathrm{Cu}(\mathrm{En})_{2}^{+1}$ & $(\mathrm{Aq})+\mathrm{Cu}^{+}+2 \mathrm{En}$ \\
\hline $230 Z 225$ & 10.20 & $\mathrm{Cu}(\mathrm{En})(\mathrm{OH})$ & $(\mathrm{Aq})+\mathrm{Cu}^{+}+\mathrm{En}+\mathrm{H}_{2} \mathrm{O}-\mathrm{H}^{+}$ \\
\hline $330 z z 24$ & 9.70 & $(\mathrm{En}) \mathrm{H}^{+1}$ & $(\mathrm{Aq})+\mathrm{En}+\mathrm{H}^{+}$ \\
\hline $330 z Z 25$ & 16.50 & $\left(E_{n}\right) H_{2}^{+2}$ & $(A q)+E n+2 H^{+}$ \\
\hline
\end{tabular}

\subsubsection{Ethylenediaminetetraacetates}

IABLE 3.8. Thermochemical Additions for Ethylenediaminetetraacetates

\begin{tabular}{|c|c|c|c|}
\hline ID & $\log (K)$ & Product & $\begin{array}{r}\text { Reaction } \\
\end{array}$ \\
\hline$\overline{1500 \mathrm{VN} 4}$ & 10.70 & $\mathrm{Ca}(\text { Edta })^{-2}$ & $(\mathrm{Aq})+\mathrm{Ca}^{+2}+\mathrm{Edta}^{-4}$ \\
\hline 1500VN5 & 13.90 & $\mathrm{Ca}(\mathrm{Edta}) \mathrm{H}^{-1}$ & $(\mathrm{Aq})+\mathrm{Ca}^{+2}+\mathrm{Edta}^{-4}+\mathrm{H}^{+}$ \\
\hline $4600 \mathrm{VN} 4$ & 8.80 & $\operatorname{Mg}(E d t a)^{-2}$ & $(A q)+\mathrm{Mg}^{+2}+\mathrm{Edta}^{-4}$ \\
\hline 4600VN5 & 12.60 & $\operatorname{Mg}(E d t a) H^{-1}$ & $(\mathrm{Aq})+\mathrm{Mg}^{+2}+\mathrm{Edta}^{-4}+\mathrm{H}^{+}$ \\
\hline 8000 VN4 & 11.00 & $S r(E d t a)^{-2}$ & $(A q)+S r^{+2}+E d t a^{-4}$ \\
\hline $8000 V N 5$ & 16.20 & $\operatorname{Sr}($ Edta $) H^{-1}$ & $(\mathrm{Aq})+\mathrm{Sr}^{+2}+\mathrm{Edta}^{-4}+\mathrm{H}^{+}$ \\
\hline $4100 \mathrm{VN} 4$ & 0.80 & $k(E d t a)^{-3}$ & $(A q)+K^{+}+E d t a-4$ \\
\hline 5000 VN 4 & 1.70 & $\mathrm{Na}(\text { Edta })^{-3}$ & $(\mathrm{Aq})+\mathrm{Na}^{+}+\mathrm{Edta}^{-4}$ \\
\hline 2810VN4 & 25.10 & $\mathrm{Fe}(\text { Edta })^{-1}$ & $(A q)+\mathrm{Fe}^{+3}+\mathrm{Edta}^{-4}$ \\
\hline 2810 VN5 & 26.40 & $\mathrm{Fe}(E d t a) H$ & $(\mathrm{Aq})+\mathrm{Fe}^{+3}+\mathrm{Edta}^{-4}+\mathrm{H}^{+}$ \\
\hline $2810 \mathrm{VN} 6$ & 21.00 & $\mathrm{Fe}(\mathrm{Edta})(\mathrm{OH})^{-2}$ & $(\mathrm{Aq})+\mathrm{Fe}^{+3}+\mathrm{Edta}^{-4}+\mathrm{H}_{2} \mathrm{O}-\mathrm{H}^{+}$ \\
\hline 2810VN7 & 10.90 & $\mathrm{Fe}(\mathrm{Edta})(\mathrm{OH})_{2}^{-3}$ & $(\mathrm{Aq})+\mathrm{Fe}^{+3}+\mathrm{Edta}^{-4}+2 \mathrm{H}_{2} \mathrm{O}-2 \mathrm{H}^{+}$ \\
\hline $2800 \mathrm{VN} 4$ & 14.30 & $\mathrm{Fe}(\text { Edta })^{-2}$ & $(\mathrm{Aq})+\mathrm{Fe}^{+2}+\mathrm{Edta}^{-4}$ \\
\hline 2800 VN5 & 17.10 & $\mathrm{Fe}(\mathrm{Edta}) \mathrm{H}^{-1}$ & $(\mathrm{Aq})+\mathrm{Fe}^{+2}+\mathrm{Edta}^{-4}+\mathrm{H}^{+}$ \\
\hline $4700 \mathrm{VN} 4$ & 13.90 & $\operatorname{Mn}(E d t a)^{-2}$ & $(A q)+M_{n}^{+2}+E d t a^{-4}$ \\
\hline 4700 VN5 & 17.00 & $\operatorname{Mn}($ Edt a $) H^{-1}$ & $(\mathrm{Aq})+\mathrm{Mn}^{+2}+\mathrm{Edta}^{-4}+\mathrm{H}^{+}$ \\
\hline 2310VN4 & 18.80 & $\operatorname{Cu}(\operatorname{Edta})^{-2}$ & $(\mathrm{Aq})+\mathrm{Cu}^{+2}+\mathrm{Edta}^{-4}$ \\
\hline $2310 \mathrm{VN} 5$ & 21.80 & $\mathrm{Cu}(\mathrm{Edt} \mathrm{a}) \mathrm{H}^{-1}$ & $(\mathrm{Aq})+\mathrm{Cu}^{+2}+\mathrm{Edta}^{-4}+\mathrm{H}^{+}$ \\
\hline 2310vN6 & 21.32 & $\mathrm{Cu}(\mathrm{Edta})(\mathrm{OH})^{-3}$ & $(\mathrm{Aq})+\mathrm{Cu}^{+2}+\mathrm{Edta}^{-4}+\mathrm{H}_{2} \mathrm{O}-\mathrm{H}^{+}$ \\
\hline 1000 VN4 & 10.20 & $\mathrm{Ba}(E d t a)^{-2}$ & $(A q)+B a^{+2}+E d t a^{-4}$ \\
\hline 1000 VN5 & 15.40 & $\mathrm{Ba}($ Edta $) \mathrm{H}^{-1}$ & $(\mathrm{Aq})+\mathrm{Ba}^{+2}+\mathrm{Edta}^{-4}+\mathrm{H}^{+}$ \\
\hline 1600 VN 4 & 16.50 & $C d(E d t a)^{-2}$ & $(\mathrm{Aq})+\mathrm{Cd}^{+2}+\mathrm{Edta}^{-4}$ \\
\hline
\end{tabular}


TABLE 3.8. (Contd)

\begin{tabular}{|c|c|c|c|c|}
\hline ID & $\log (K)$ & Product & & Reaction \\
\hline$\overline{1600 \text { VN5 }}$ & 19.40 & $\operatorname{Cd}\left(\right.$ Edta) $H^{-1}$ & $(\mathrm{Aq})+\mathrm{Cd}^{+2}$ & $+\mathrm{Edta}^{-4}+\mathrm{H}^{+}$ \\
\hline 9500 VN4 & 16.50 & $\operatorname{Zn}\langle\text { Edta })^{-2}$ & $(A q)+Z n^{+2}$ & $+\operatorname{Edta}^{-4}$ \\
\hline 9500 vN5 & 19.50 & $\operatorname{Zn}($ Edta $) H^{-1}$ & $(A q)+Z_{n}^{+2}$ & $+\mathrm{Edta}^{-4}+\mathrm{H}^{+}$ \\
\hline 9500VN6 & 18.60 & $\operatorname{Zn}(\operatorname{Edt} a)(\mathrm{OH})^{-3}$ & $(A q)+Z^{+2}$ & $+\mathrm{Edta}^{-4}+\mathrm{H}_{2} \mathrm{O}-\mathrm{H}^{+}$ \\
\hline 5400 VN4 & 18.60 & $N i(\text { Edta })^{-2}$ & $(\mathrm{Aq})+\mathrm{Ni}^{+2}$ & $+E d t a^{-4}$ \\
\hline 5400 VN5 & 21.80 & $\mathrm{Ni}($ Edta $) \mathrm{H}^{-1}$ & $(\mathrm{Aq})+\mathrm{Ni}^{+2}$ & $+\mathrm{Edta}^{-4}+\mathrm{H}^{+}$ \\
\hline 5400 VN6 & 20.40 & $\mathrm{Ni}($ Edta $)(\mathrm{OH})^{-3}$ & $(\mathrm{Aq})+\mathrm{Ni}+2$ & $+\mathrm{Edta}^{-4}+\mathrm{H}_{2} \mathrm{O}-\mathrm{H}^{+}$ \\
\hline 3600VN4 & 24.20 & $\mathrm{Hg}(\text { Edt } \mathrm{a})^{-2}$ & $(\mathrm{Aq})+\mathrm{Hg}^{+2}$ & $+\mathrm{Edta}^{-4}$ \\
\hline 3600 VN5 & 27.90 & $\mathrm{Hg}($ Edta $) H^{-1}$ & $(\mathrm{Aq})+\mathrm{Hg}^{+2}$ & $+\mathrm{Edta}^{-4}+\mathrm{H}^{+}$ \\
\hline 3600 VN6 & 14.50 & $\mathrm{Hg}(\mathrm{Edt} \mathrm{a})(\mathrm{OH})^{-3}$ & $(\mathrm{Aq})+\mathrm{Hg}^{+2}$ & $+\mathrm{Edta}^{-4}+\mathrm{H}_{2} \mathrm{O}-\mathrm{H}^{+}$ \\
\hline 6000VN4 & 18.00 & $\mathrm{~Pb}($ Edta $)-2$ & $(A q)+P b^{+2}$ & $+\operatorname{Edta}^{-4}$ \\
\hline 6000VN5 & 20.80 & $\mathrm{~Pb}($ Edt $a) H^{-1}$ & $(\mathrm{Aq})+\mathrm{Pb}^{+2}$ & $+\mathrm{Edta}^{-4}+\mathrm{H}^{+}$ \\
\hline 2000 VN4 & 16.30 & $\operatorname{Co}(\text { Edta })^{-2}$ & $(\mathrm{Aq})+\mathrm{Co}^{+2}$ & $+E_{d t a}-4$ \\
\hline 2000VN5 & 19.30 & $\operatorname{Co}(E d t a) H^{-1}$ & $(\mathrm{Aq})+\mathrm{Co}^{+2}$ & $+\operatorname{Edta}^{-4}+\mathrm{H}^{+}$ \\
\hline 2010VN4 & 39.80 & $\operatorname{Co}(E d t a)^{-1}$ & $(\mathrm{Aq})+\mathrm{CO}^{+3}$ & $+\operatorname{Edta}^{-4}$ \\
\hline 2010 VN5 & 41.20 & $\mathrm{Co}(\operatorname{Edt} \mathrm{a}) \mathrm{H}$ & $(\mathrm{Aq})+\mathrm{CO}^{+3}$ & $+\mathrm{Edta}^{-4}+\mathrm{H}^{+}$ \\
\hline 0200VN4 & 8.40 & $\mathrm{Ag}(\mathrm{Edta})^{-3}$ & $(\mathrm{Aq})+\mathrm{Ag}^{+}$ & $+\operatorname{Edta}^{-4}$ \\
\hline 0200vN5 & 15.30 & $\mathrm{Ag}(\mathrm{Edta}) \mathrm{H}^{-2}$ & $(\mathrm{Aq})+\mathrm{Ag}^{+}$ & $+\mathrm{Edta}^{-4}+\mathrm{H}^{+}$ \\
\hline 2150VN4 & 26.80 & $\operatorname{Cr}(\text { Edta })^{-1}$ & $(\mathrm{Aq})+\mathrm{Cr}^{+3}$ & $+\operatorname{Edta}^{-4}$ \\
\hline 2150 VN5 & 29.20 & $\mathrm{Cr}(\mathrm{Edta} \mathrm{a} \mathrm{H}$ & $(\mathrm{Aq})+\mathrm{Cr}^{+3}$ & $+\operatorname{Edta}^{-4}+\mathrm{H}^{+}$ \\
\hline 2150VN6 & 19.00 & $\mathrm{Cr}(\mathrm{Edta})(\mathrm{OH})^{-2}$ & $(\mathrm{Aq})+\mathrm{Cr}^{+3}$ & $+\mathrm{Edta}^{-4}+\mathrm{H}_{2} \mathrm{O}-\mathrm{H}^{+}$ \\
\hline 0300VN4 & 16.30 & $A l(\text { Edt } a)^{-1}$ & $(A q)+A l^{+3}$ & $+\mathrm{Edta}^{-4}$ \\
\hline 0300VN5 & 18.80 & $\mathrm{~A} 1(\mathrm{Edta}) \mathrm{H}$ & $(A q)+A]^{+3}$ & $+\mathrm{Edta}^{-4}+\mathrm{H}^{+}$ \\
\hline 0300VN6 & 13.60 & $A 1\left(\right.$ Edta) $(O H)^{-2}$ & $(A q)+A I^{+3}$ & $+\mathrm{Edta}^{-4}+\mathrm{H}_{2} \mathrm{O}-\mathrm{H}^{+}$ \\
\hline 2200 VN4 & 1.40 & $\operatorname{Cs}(\text { Edta })^{-3}$ & $(\mathrm{Aq})+\mathrm{Cs}^{+}$ & $+\mathrm{Edta}^{-4}$ \\
\hline 4400 VN4 & 4.00 & $L i(E d t a)^{-3}$ & $(\mathrm{Aq})+\mathrm{Li}^{+}$ & $+\mathrm{Edta}^{-4}$ \\
\hline 1100 VN4 & 12.70 & $B e(\text { Edta })^{-2}$ & $(A q)+B e^{+2}$ & $+\operatorname{Edta}^{-4}$ \\
\hline $7500 \vee N 4$ & 26.90 & $S c(E d t a)^{-1}$ & $(A q)+\mathrm{Sc}^{+3}$ & $+\operatorname{Edta}^{-4}$ \\
\hline 7500 vN5 & 16.10 & $S c$ (Edta) $(\mathrm{OH})^{-2}$ & $(\mathrm{Aq})+\mathrm{Sc}^{+3}$ & $+\mathrm{Edta}^{-4}+\mathrm{H}_{2} \mathrm{O}-\mathrm{H}^{+}$ \\
\hline 8600 VN4 & 20.00 & $\mathrm{TiO}(\text { Edt } a)^{-2}$ & $(A q)+\mathrm{TiO}^{+2}$ & $+\operatorname{Edta}^{-4}$ \\
\hline 7900 VN4 & 24.60 & $\operatorname{Sn}(E d t a)^{-2}$ & $(A q)+S^{+2}$ & $+\operatorname{Edta}^{-4}$ \\
\hline 4300 VN4 & 19.20 & $\operatorname{La}(\text { Edta })^{-1}$ & $(\mathrm{Aq})+\mathrm{La}^{+3}$ & $+E_{d t a}-4$ \\
\hline
\end{tabular}


TABLE 3.8. (Contd)

\begin{tabular}{|c|c|c|c|c|}
\hline ID & $\log (K)$ & Product & & Reaction \\
\hline $4300 \mathrm{VN5}$ & 21.40 & $\mathrm{La}(\mathrm{Edta}) \mathrm{H}$ & $(A q)+L a^{+3}$ & $+\mathrm{Edta}^{-4}+\mathrm{H}^{+}$ \\
\hline $1700 \mathrm{VN} 4$ & 20.10 & $\mathrm{Ce}(\mathrm{Edt} \mathrm{a})^{-1}$ & $(\mathrm{Aq})+\mathrm{Ce}^{+3}$ & $+\operatorname{Edta}^{-4}$ \\
\hline $8500 \mathrm{VN} 4$ & 28.30 & $\operatorname{Th}(E d t a)$ & $(A q)+T h^{+4}$ & $+E_{d t a}-4$ \\
\hline 85 00VN5 & 21.30 & $\operatorname{Th}(E d t a)(O H)^{-1}$ & $(\mathrm{Aq})+\mathrm{Th}^{+4}$ & $+\mathrm{Edta}^{-4}+\mathrm{H}_{2} \mathrm{O}-\mathrm{H}^{+}$ \\
\hline 8930 VN4 & 12.90 & $\mathrm{UO}_{2}(E \mathrm{dta})^{-2}$ & $(A q)+u 0_{2}^{+2}$ & $+\operatorname{Edta}^{-4}$ \\
\hline 8930 VN5 & 20.70 & $\mathrm{UO}_{2}($ Edt a $) \mathrm{H}^{-1}$ & $(A q)+U 0_{2}^{+2}$ & $+\mathrm{Edta}^{-4}+\mathrm{H}^{+}$ \\
\hline 8930 VN6 & 21.60 & $\left(\mathrm{UO}_{2}\right)_{2}(\mathrm{Edta})$ & $(\mathrm{Aq})+2 \mathrm{UO}_{2}^{+2}$ & $+E d t a^{-4}$ \\
\hline $3300 \mathrm{VN} 4$ & 10.20 & $(E d t a) H^{-3}$ & $(A q)+E d t d^{-4}$ & $+\mathrm{H}^{+}$ \\
\hline 3300VN5 & 16.40 & $(E d t a) H_{2}^{-2}$ & $(A q)+E d t a^{-4}$ & $+2 \mathrm{H}^{+}$ \\
\hline 3300 VN6 & 19.00 & $(E d t a) H_{3}^{-1}$ & $(A q)+E d t a^{-4}$ & $+3 \mathrm{H}^{+}$ \\
\hline 3300VN7 & 21.10 & $(\mathrm{Edta}) \mathrm{H}_{4}$ & $(A q)+E d t a^{-4}$ & $+4 \mathrm{H}^{+}$ \\
\hline 3300 VN8 & 22.60 & $(E d t a) H_{5}^{+1}$ & $(A q)+E d t a^{-4}$ & $+5 \mathrm{H}^{+}$ \\
\hline 3300VN9 & 24.40 & $(E d t a) H_{6}^{+2}$ & $(A q)+E d t a^{-4}$ & $+6 \mathrm{H}^{+}$ \\
\hline
\end{tabular}

\subsubsection{Nitrilotriacetates}

TABLE 3.9. Thermochemical Additions for Nitrilotriacetates

\begin{tabular}{|c|c|c|c|c|}
\hline I0 & $\log (K)$ & Product & & Reaction \\
\hline 150 N $\vee 34$ & 8.20 & $\mathrm{Ca}(\mathrm{Nta})^{-1}$ & $(A q)+\mathrm{Ca}^{+2}$ & $\mathrm{Nt} \mathrm{a}{ }^{-3}$ \\
\hline 460NV34 & 7.20 & $\operatorname{Mg}(\text { Net a })^{-1}$ & $(\mathrm{Aq})+\mathrm{Mg}^{+2}$ & Net $a^{-3}$ \\
\hline 800 NV34 & 6.90 & $\operatorname{Sr}(N t a)^{-1}$ & $(\mathrm{Aq})+\mathrm{Sr}^{+2}$ & $N t a^{-3}$ \\
\hline 500 NV 34 & 2.40 & $\mathrm{Na}(\mathrm{Net} a)^{-2}$ & $(\mathrm{Aq})+\mathrm{Na}^{+}$ & Nt $a^{-3}$ \\
\hline 281 NV 34 & 18.60 & $\mathrm{Fe}(\mathrm{Nta})$ & $(\mathrm{Aq})+\mathrm{Fe}^{+3}$ & $\mathrm{Nt} \mathrm{a}^{-3}$ \\
\hline 281 NV35 & 27.10 & $\mathrm{Fe}(\mathrm{Nt} \mathrm{a})_{2}^{-3}$ & $(\mathrm{Aq})+\mathrm{Fe}^{+3}$ & $+2 \mathrm{Nta}^{-3}$ \\
\hline 281 NV36 & 14.60 & $\mathrm{Fe}(\mathrm{Nta})(\mathrm{OH})^{-1}$ & $(\mathrm{Aq})+\mathrm{Fe}^{+3}$ & $+\mathrm{Nta}^{-3}+\mathrm{H}_{2} \mathrm{O}-\mathrm{H}^{+}$ \\
\hline 281 NV37 & 6.30 & $\mathrm{Fe}$ (N $\mathrm{Na})(\mathrm{OH})_{2}^{-2}$ & $(\mathrm{Aq})+\mathrm{Fe}^{+3}$ & $\mathrm{Nta}^{-3}+2 \mathrm{H}_{2} \mathrm{O}-2 \mathrm{H}^{+}$ \\
\hline 280 NV34 & 10.60 & $\mathrm{Fe}(\mathrm{Nta})^{-1}$ & $(A q)+F e^{+2}$ & $\mathrm{Nta}^{-3}$ \\
\hline 280 NV35 & -00.10 & $\mathrm{Fe}(\mathrm{Nt} \mathrm{a})(\mathrm{OH})^{-2}$ & $(\mathrm{Aq})+\mathrm{Fe}^{+2}$ & $\mathrm{Nt} \mathrm{a}^{-3}+\mathrm{H}_{2} \mathrm{O}-\mathrm{H}^{+}$ \\
\hline 470 NV34 & 9.20 & $M n(N t a)^{-1}$ & $(\mathrm{Aq})+\mathrm{Mn}^{+2}$ & $\mathrm{Nt} \mathrm{a}^{-3}$ \\
\hline 231 NV34 & 14.50 & $\mathrm{Cu}(\mathrm{Nt} a)^{-1}$ & $(\mathrm{Aq})+\mathrm{Cu}^{+2}$ & $N a^{-3}$ \\
\hline 231 NV 35 & 17.10 & $\mathrm{Cu}(\mathrm{Nta}) 2^{-4}$ & $(\mathrm{Aq})+\mathrm{Cu}^{+2}$ & $+2 N \mathrm{Na}^{-3}$ \\
\hline
\end{tabular}


TABLE 3.9. (Contd)

\begin{tabular}{|c|c|c|c|c|c|}
\hline ID & $\log (K)$ & Product & & & Reaction \\
\hline 231 NV36 & 4.90 & $\mathrm{Cu}(\mathrm{Nta})(\mathrm{OH})^{-2}$ & $(A q)$ & $+\mathrm{Cu}^{+2}$ & $+\mathrm{Nta}^{-3}+\mathrm{H}_{2} \mathrm{O}-\mathrm{H}^{+}$ \\
\hline 100 NV34 & 6.50 & $B a(N t a)^{-1}$ & (Aq) & $+\mathrm{Ba}^{+2}$ & $+N \mathrm{a}^{-3}$ \\
\hline 160 NV 34 & 11.90 & $\operatorname{Cd}(N \mathrm{Na})^{-1}$ & $(\mathrm{Aq})$ & $+\mathrm{Cd}^{+2}$ & $+\mathrm{Nta}^{-3}$ \\
\hline 160 NV35 & 15.40 & $\operatorname{Cd}(N \mathrm{~N} a))_{2}^{-4}$ & (Aq) & $+\mathrm{Cd}^{+2}$ & $+2 \mathrm{Nta}^{-3}$ \\
\hline 950 NV34 & 12.40 & $\operatorname{Zn}(N+a)^{-1}$ & $(A q)$ & $+\mathrm{Zn}^{+2}$ & $+\mathrm{Nta}^{-3}$ \\
\hline 950 NV35 & 14.20 & $\ln (\mathrm{Nt} a) 2_{2}^{-4}$ & (Aq) & $+2 n+2$ & $+2 \mathrm{Nta}^{-3}$ \\
\hline 540 NV34 & 13.10 & $\mathrm{Ni}(\mathrm{Nta})^{-1}$ & (Aq) & $+\mathrm{Ni}^{+2}$ & $+\quad \mathrm{Nta}^{-3}$ \\
\hline 360 NV34 & 14.50 & $\mathrm{Hg}(\mathrm{Nt} \mathrm{a})^{-1}$ & (Aq) & $+\mathrm{Hg}^{+2}$ & Nt a ${ }^{-3}$ \\
\hline 360 NV35 & 8.80 & $\mathrm{Hg}(\mathrm{Nta})(\mathrm{OH})^{-2}$ & $(A q)$ & $+\mathrm{Hg}^{+2}$ & $+\mathrm{Nta}^{-3}+\mathrm{H}_{2} \mathrm{O}-\mathrm{H}^{+}$ \\
\hline 600 NV 34 & 13.60 & $\mathrm{~Pb}(\text { Nt } a)^{-1}$ & (Aq) & $+\mathrm{Pb}^{+2}$ & $\mathrm{Nt} \mathrm{a}^{-3}$ \\
\hline $200 N \vee 34$ & 12.40 & $\operatorname{Co}(N t a)^{-1}$ & $(\mathrm{Aq})$ & $+\mathrm{Co}^{+2}$ & $\mathrm{Nta} \cdot 3$ \\
\hline 030NV34 & 14.80 & $A 1($ Nt a $)$ & (Aq) & $+\mathrm{Al}^{+3}$ & $+\mathrm{Nt} \mathrm{a}^{-3}$ \\
\hline 030NV35 & 20.80 & $\mathrm{~A} 1(\mathrm{Nta}) 2^{-3}$ & (Aq) & $+\mathrm{Al}^{+3}$ & $+2 \mathrm{Nt}^{-3}$ \\
\hline 030NV36 & 9.40 & $\mathrm{~A} 1(\mathrm{Nt}$ a $)(\mathrm{OH})^{-1}$ & (Aq) & $+\mathrm{Al}^{+3}$ & $+\quad \mathrm{Nta} \mathrm{a}^{-3}+\mathrm{H}_{2} \mathrm{O}-\mathrm{H}^{+}$ \\
\hline 110 NV34 & 9.00 & $\mathrm{Be}(\mathrm{Nta})^{-1}$ & $(\mathrm{Aq})$ & $+B e^{+2}$ & $\mathrm{Nta}^{-3}$ \\
\hline 860 NV34 & 14.20 & $\mathrm{TiO}(\mathrm{Nt} a)^{-1}$ & (Aq) & $+\mathrm{TiO}^{+2}$ & $N a^{-3}$ \\
\hline 430 NV34 & 13.20 & $\operatorname{La}(N t a)$ & (Aq) & $+\mathrm{La}^{+3}$ & $+\mathrm{Nta} a^{-3}$ \\
\hline 430 NV35 & 20.90 & $\operatorname{La}($ Nt $a) 2_{2}^{-3}$ & $(\mathrm{Aq})$ & $+\mathrm{La}^{+3}$ & $+2 \mathrm{Nt}^{-3}$ \\
\hline 170 NV34 & 13.50 & $\mathrm{Ce}(\mathrm{Nta})$ & $(\mathrm{Aq})$ & $+\mathrm{Ce}^{+3}$ & $+N t \mathrm{a}^{-3}$ \\
\hline 17 ONV35 & 21.40 & $\mathrm{Ce}(\mathrm{Nt} \mathrm{a})_{2}^{-3}$ & (Aq) & $+\mathrm{Ce}^{+3}$ & $+2 \mathrm{Nta}^{-3}$ \\
\hline 850 NV34 & 17.10 & $\operatorname{Th}(N t a)^{+1}$ & $(\mathrm{Aq})$ & $+\mathrm{Th}^{+4}$ & $+\quad N t a^{-3}$ \\
\hline 850 NV 35 & -17.20 & $\operatorname{Th}\left(\mathrm{Nt}\right.$ a) $(\mathrm{OH}) 2_{2}^{-1}$ & (Aq) & $+\mathrm{Th}^{+4}$ & $+\quad \mathrm{Nt} \mathrm{a} \mathrm{a}^{-3}+2 \mathrm{H}_{2} \mathrm{O}-2 \mathrm{H}^{+}$ \\
\hline $893 N \vee 34$ & 11.50 & $002(\mathrm{Nta})^{-1}$ & $(\mathrm{Aq})$ & $+\mathrm{UO}_{2}{ }^{+2}$ & $+\mathrm{Nta}^{-3}$ \\
\hline 330 NV34 & 10.50 & $(\mathrm{Nt} a) \mathrm{H}^{-2}$ & (Aq) & $+N t a^{-3}$ & $+\mathrm{H}^{+}$ \\
\hline 330 NV35 & 13.70 & $(\mathrm{Nt} \mathrm{a}) \mathrm{H}_{2}^{-1}$ & $(\mathrm{Aq})$ & $+\mathrm{Nt} a^{-3}$ & $+2 \mathrm{H}^{+}$ \\
\hline 330 NV36 & 15.90 & (Nt a ) $\mathrm{H}_{3}$ & (Aq) & $+N t a^{-3}$ & $+3 \mathrm{H}^{+}$ \\
\hline
\end{tabular}


3.4 .7 0xalates

TABLE 3.10. Thermochemical Additions for 0xalates

\begin{tabular}{|c|c|c|c|c|}
\hline ID & $\log (K)$ & Product & & Reaction \\
\hline 9115001 & 8.00 & $\mathrm{Ca}(0 \mathrm{x})$ & (So $)+\mathrm{Ca}^{+2}$ & $+0 x^{-2}$ \\
\hline 150VV04 & 3.60 & $\mathrm{Ca}(0 \mathrm{x})$ & $(\mathrm{Aq})+\mathrm{Ca}^{+2}$ & $0 x^{-2}$ \\
\hline 9146001 & 3.70 & $\operatorname{Mg}(0 x)$ & (So) $+\mathrm{Mg}^{+2}$ & $+0 x^{-2}$ \\
\hline 460VV04 & 2.90 & $\operatorname{Mg}(0 x)$ & $(\mathrm{Aq})+\mathrm{Mg}^{+2}$ & $0 x^{-2}$ \\
\hline 9180001 & 6.70 & $\operatorname{sr}(0 x)$ & $(\mathrm{So})+\mathrm{Sr}^{+2}$ & $+0 x^{-2}$ \\
\hline 800 VV0 4 & 1.90 & $\operatorname{Sr}(0 x)$ & $(\mathrm{Aq})+\mathrm{Sr}^{+2}$ & $+0 x^{-2}$ \\
\hline 281 V 04 & 8.90 & $\mathrm{Fe}(0 x)^{+1}$ & $(\mathrm{Aq})+\mathrm{Fe}^{+3}$ & $0 x^{-2}$ \\
\hline 281vv05 & 15.70 & $\mathrm{Fe}(0 x) 2^{-1}$ & $(\mathrm{Aq})+\mathrm{Fe}^{+3}$ & $+20 x^{-2}$ \\
\hline $281 \vee v 06$ & 20.40 & $\mathrm{Fe}(0 x) 3^{-3}$ & $(A q)+F e^{+3}$ & $+30 x-2$ \\
\hline 470 V0 4 & 3.20 & $\operatorname{Mn}(0 x)$ & $(\mathrm{Aq})+M n^{+2}$ & $+0 x^{-2}$ \\
\hline $470 v v 05$ & 4.90 & $\operatorname{Mn}(0 x)_{2}^{-2}$ & $(A q)+M n+2$ & $+20 x^{-2}$ \\
\hline $231 \vee v 04$ & 6.40 & $\mathrm{Cu}(0 x) \mathrm{H}^{+1}$ & $(\mathrm{Aq})+\mathrm{Cu}^{+2}$ & $+\quad 0 x^{-2}+H^{+}$ \\
\hline $231 \vee v 05$ & 5.10 & $\operatorname{cu}(0 x)$ & $(\mathrm{Aq})+\mathrm{Cu}^{+2}$ & $0 x^{-2}$ \\
\hline 231พv06 & 9.70 & $\mathrm{Cu}(0 x)_{2}^{-2}$ & $(\mathrm{Aq}) \times \mathrm{Cu}^{+2}$ & $+20 x^{-2}$ \\
\hline 9110001 & 6.20 & $\mathrm{Ba}(0 \mathrm{x})$ & (So) $+\mathrm{Ba}^{+2}$ & $+0 x^{-2}$ \\
\hline 100vv04 & 1.70 & $\mathrm{Ba}(0 \mathrm{x})$ & $(\mathrm{Aq})+\mathrm{Ba}^{+2}$ & $0 x^{-2}$ \\
\hline 9116001 & 7.20 & $\operatorname{cd}(0 x)$ & $(\mathrm{SO})+\mathrm{Cd}^{+2}$ & $0 x^{-2}$ \\
\hline 160VV04 & 3.40 & $\operatorname{cd}(0 x)$ & $(\mathrm{Aq})+\mathrm{Cd}^{+2}$ & $0 x^{-2}$ \\
\hline $160 \mathrm{Vv} 05$ & 5.50 & $c d(0 x)_{2}^{-2}$ & $(\mathrm{Aq})+\mathrm{Cd}^{+2}$ & $+20 x^{-2}$ \\
\hline 9195001 & 8.20 & $\operatorname{Zn}(0 x)$ & (So) $+\mathrm{Zn}^{+2}$ & $+0 x^{-2}$ \\
\hline 950VV04 & 4.20 & $\operatorname{Zn}(0 x)$ & $(A q)+Z n^{+2}$ & $+0 x^{-2}$ \\
\hline $950 \mathrm{VY} 05$ & 6.90 & $\operatorname{Zn}(0 x)_{2}^{-2}$ & $(\mathrm{Aq})+\mathrm{Zn}^{+2}$ & $+20 x^{-2}$ \\
\hline 950VV06 & 5.70 & $\operatorname{Zn}(0 x) H^{+1}$ & $(A q)+Z n+2$ & $+0 x^{-2}+H^{+}$ \\
\hline 950v07 & 11.10 & $\mathrm{Zn}(0 \mathrm{x}){ }_{2} \mathrm{H}_{2}$ & $(A q)+2 n^{+2}$ & $+20 x^{-2}+2 H^{+}$ \\
\hline 540VV04 & 4.60 & $\operatorname{Ni}(0 x)$ & $(\mathrm{Aq})+\mathrm{Ni}+2$ & $+0 x^{-2}$ \\
\hline 540 vo5 & 8.00 & $\mathrm{Ni}(0 x)_{2}^{-2}$ & $(\mathrm{Aq})+\mathrm{Ni}^{+2}$ & $+20 x^{-2}$ \\
\hline $540 v$ vo & 9.40 & $\mathrm{Ni}(0 x)^{-4}$ & $(\mathrm{Aq})+\mathrm{Ni}+2$ & $+30 x^{-2}$ \\
\hline 9160001 & 9.20 & $\mathrm{~Pb}(0 \mathrm{x})$ & $\left(S_{0}\right)+P_{b}+2$ & $+0 x^{-2}$ \\
\hline 200VV04 & 4.10 & $\operatorname{Co}(0 x)$ & $(\mathrm{Aq})+\mathrm{CO}^{+2}$ & $+0 x^{-2}$ \\
\hline 200VV05 & 6.60 & $\operatorname{Co}(0 x)_{2}^{-2}$ & $(\mathrm{Aq})+\mathrm{Co}^{+2}$ & $+20 x^{-2}$ \\
\hline
\end{tabular}


TABLE 3.10. (Contd)

\begin{tabular}{|c|c|c|c|c|c|}
\hline ID & $\log (K)$ & Product & \multicolumn{3}{|c|}{ Reaction } \\
\hline 200vv06 & 5.70 & $\mathrm{Co}(0 x) H^{+1}$ & (Aq) & $+\mathrm{Co}^{+2}$ & $+\quad 0 x^{-2}+H^{+}$ \\
\hline 200VV07 & 10.90 & $\mathrm{Co}(\mathrm{Ox})_{2} \mathrm{H}_{2}$ & (Aq) & $+\mathrm{CO}^{+2}$ & $+20 x^{-2}+2 H^{+}$ \\
\hline 9102001 & 10.40 & $\operatorname{Ag} 2(0 x)$ & (So) & $+2 \mathrm{Ag}^{+}$ & $+0 x^{-2}$ \\
\hline 020vvo4 & 2.60 & $\operatorname{Ag}(0 x)^{-1}$ & $(\mathrm{Aq})$ & $+\mathrm{Ag}^{+}$ & $0 x^{-2}$ \\
\hline 215VV04 & 6.40 & $\operatorname{Cr}(0 x)^{+1}$ & $(\mathrm{Aq})$ & $+\mathrm{Cr}^{+3}$ & $+0 x^{-2}$ \\
\hline 030VV04 & 12.50 & $A 1(0 x) 2^{-1}$ & $(\mathrm{Aq})$ & $+\mathrm{Al}^{+3}$ & $+20 x^{-2}$ \\
\hline 030VV05 & 16.40 & $A 1(0 x)_{3}^{-3}$ & $(\mathrm{Aq})$ & $+\mathrm{Al}^{+3}$ & $+30 x^{-2}$ \\
\hline 110VvD4 & 4.20 & $\operatorname{Be}(0 x)$ & (Aq) & $+B e^{+2}$ & $+0 x^{-2}$ \\
\hline 110rv05 & 6.30 & $\operatorname{Be}(0 x)_{2}^{-2}$ & $(\mathrm{Aq})$ & $+B e^{+2}$ & $+20 x^{-2}$ \\
\hline $750 \vee v 04$ & 18.20 & $\sec (0 x)^{-3}$ & (Aq) & $+\mathrm{Sc}^{+3}$ & $+30 x^{-2}$ \\
\hline 860VV04 & 10.30 & $\operatorname{TiO}(0 x)$ & $(\mathrm{Aq})$ & $+\mathrm{TiO}^{+2}$ & $+0 x^{-2}$ \\
\hline 860Vv05 & 15.70 & Tio $(0 x) 2^{-2}$ & $(\mathrm{Aq})$ & $+\mathrm{TiO}^{+2}$ & $+20 x^{-2}$ \\
\hline 430พv04 & 5.20 & $\operatorname{La}(0 x)^{+1}$ & $(\mathrm{Aq})$ & $+\mathrm{La}^{+3}$ & $+0 x^{-2}$ \\
\hline 430vv05 & 9.40 & $\operatorname{La}(0 x)_{2}^{-1}$ & $(A q)$ & $+\mathrm{La}^{+3}$ & $+20 x^{-2}$ \\
\hline 430vV06 & 12.20 & $\operatorname{La}(0 x))^{-3}$ & $(\mathrm{Aq})$ & $+\mathrm{La}^{+3}$ & $+30 x^{-2}$ \\
\hline 170vv04 & 6.80 & $\mathrm{Ce}(0 x)^{+1}$ & $(\mathrm{Aq})$ & $+\mathrm{Ce}^{+3}$ & $+0 x^{-2}$ \\
\hline 170VV05 & 10.70 & $\mathrm{Ce}(0 x)_{2}^{-1}$ & $(\mathrm{Aq})$ & $+\mathrm{Ce}^{+3}$ & $+20 x^{-2}$ \\
\hline 170vv06 & 11.60 & $\mathrm{Ce}(0 x)^{-3}$ & $(\mathrm{Aq})$ & $+\mathrm{Ce}^{+3}$ & $+30 x^{-2}$ \\
\hline $893 \vee V 04$ & 5.20 & $\mathrm{vO}_{2}(0 x)$ & (Aq) & $+\mathrm{UO}_{2}^{+2}$ & $+0 x^{-2}$ \\
\hline 893vV05 & 9.60 & $\mathrm{NO}_{2}(0 x)_{2}^{-2}$ & $(\mathrm{Aq})$ & $+40_{2}^{+2}$ & $+20 x^{-2}$ \\
\hline 893 V06 & 12.90 & $\mathrm{vO}_{2}(0 x)^{-4}$ & $(\mathrm{Aq})$ & $+v_{2}^{+2}$ & $+30 x^{-2}$ \\
\hline $330 v \vee 04$ & 4.20 & $(0 x) H^{-1}$ & $(A q)$ & $+0 x^{-2}$ & $+\mathrm{H}^{+}$ \\
\hline 330v05 & 5.10 & $(0 x) H_{2}$ & $(A q)$ & $+0 x^{-2}$ & $+2 \mathrm{H}^{+}$ \\
\hline
\end{tabular}




\subsection{RECOMMENDATIONS FOR FURTHER WORK}

Thermochemical data in this report coupled with the improved geochemical code MINTEQ2 provide a provisionary capability to assess some important effects of organic 1 igands on the aqueous chemistry of Hanford defense waste. We recommend their use to make preliminary assessments of the effect of organics on the solubilization or precipitation of inorganics that are found in Hanford defense wastes. The thermochemical data should also be used in computer mode1ing sensitivity exercises to determine which organic reactions could have a significant impact on Hanford defense waste management. Specific applications of MINTEQ2 could include assessment of the effects of known or hypothesized concentrations of organics in double-shell slurry and single-shell tank wastes. Knowledge of the effects of organics on these waste streams and the detailed knowledge on overall chemistry that MINTEQ2 provides will great ly help source term development efforts and subsequent calculations of waste migration in the Hanford sediments, both of which are essential elements of performance assessment analyses.

These exercises will help establish priorities in verifying the thermochemical data. Obviously, the careful evaluation of all possible metal/organic reactions would require many man-years of effort. However, most of these reactions will not be important because the organic ligand will not be in sufficient supply to make much of a difference. Others will, however, and must be identified.

We emphasize that the thermochemical data presented in this report are classified as provisionary for several reasons: 1) they have not been individually documented; 2) we cannot be assured that they are internally consistent with the existing MINTEQ2 reactions; and 3) in some cases, the reaction has had to be inferred indirectly. After the preliminary analyses have been made, important reactions have been identified, and priorities have been established, additional resources should be allocated to verify the accuracy of these important reactions as they apply to the Hanford defense waste scenario. 


\subsection{ADDING ORGANIC REACTIONS TO THE THERMODYNAMIC DATA BASE}

Notably absent from the organic data base described in this report are chemical reactions for the major radionuclides and reactions of several apparently important 1 igands for a 11 of the elements. By operating MINTEQ2 in the mode described above, some of these may be legitimately ignored. However, some are certainly expected to play important roles. For the important reactions, free energies of reactions with pertinent metal species should be added. Table 4.1 summarizes the possible future need for additional data (indicated by $x$ ) for reactions involving organic ligands.

TABLE 4.1. Additional Organic-Ligand Reactions Needed for MINTEQ2

\begin{tabular}{|c|c|c|c|c|c|c|c|c|}
\hline \multirow[b]{2}{*}{ Element } & \multicolumn{8}{|c|}{ Ligand $(a)$} \\
\hline & $0 x-$ & Edt $a-4$ & Cit-3 & Hyac-1 & Hedta-3 & Tbp & Gluc & D2ehpa \\
\hline Cobalt & & & & $x$ & $x$ & $x$ & $x$ & $x$ \\
\hline Copper & & & & $x$ & $x$ & $x$ & $x$ & $x$ \\
\hline Manganese & & & & $x$ & $x$ & $x$ & $x$ & $x$ \\
\hline Cadmí um & & & & $x$ & $x$ & $x$ & $x$ & $x$ \\
\hline Lead & & & & $x$ & $x$ & $x$ & $x$ & $x$ \\
\hline Lanthanum & & & & $x$ & $x$ & $x$ & $x$ & $x$ \\
\hline Cerium & & & & $x$ & $x$ & $x$ & $x$ & $x$ \\
\hline Cesi um & & & & $x$ & $x$ & $x$ & $x$ & $x$ \\
\hline Strontiun & & & & $x$ & $x$ & $x$ & $x$ & $x$ \\
\hline Mercury & & & & $x$ & $x$ & $x$ & $x$ & $x$ \\
\hline Lanthanum & & & & $x$ & $x$ & $x$ & $x$ & $x$ \\
\hline Urani um & & & & $x$ & $x$ & $x$ & $x$ & $x$ \\
\hline Plutonium & $x$ & $x$ & $x$ & $x$ & $x$ & $x$ & $x$ & $x$ \\
\hline Neptuni um & $x$ & $x$ & $x$ & $x$ & $x$ & $x$ & $x$ & $x$ \\
\hline
\end{tabular}

(a) Edta-4 = ethylenediaminetetraacetate; Cit-3 = citrate; Hyac-1 = hydroxyacetate; Hedta-3 = hydroxyethylenediaminetriacetate; Tbp = tributyl phosphate, Gluc = gluconate; D2ehpa = Di(2-Ethylhexyl)phosphate. 


\subsection{ADDING PITZER PARAMETERS FOR ORGANIC INTERACTIONS}

To accurately calculate activity coefficients of organic ligands in highionic-strength aqueous media, ion interaction parameters (Pitzer 1980, 1981) are needed for these ligands and for plutonium and neptunium. Because most of these probably will not be found in the literature, some effort must be extended to formulate a generalization for the organic parameters and perhaps for the plutonium and neptunium parameters.

\subsection{ADOING ADSORPTION REACTIONS}

Application of MINTEQ2 to assess disposal of defense waste will require knowledge of the important adsorption reactions for Manford soils. Therefore, the literature on Hanford soils should be examined to extract thermochemical data for adsorption reactions between the metallic species and adsorption sites on the soils.

\subsection{FURTHER MOOIFICATIONS TO MINTEQ2}

We believe that MINTEQ2 is now developed to the point that it could mode? most of the aqueous chemical problems at Hanford provided the appropriate thermochemical data were available. However, as is always the case with computer codes of this complexity, we can expect to discover deficiencies with usage that will need correction. These corrections are not expected to be a major effort, but rather will be part of an ongoing maintenance program.

Extension of MINTEQ2's capability to model adsorption at high ionic strengths will require some development of theory. Little work has yet been reported on modeling adsorption processes in concentrated aqueous media. Thus, a major scientific developmental effort is justified to develop adequate mode 1ing capabilities. Fortunately, however, applications involving high ionic strengths may only be needed relatively close to the source and then only if adsorption surfaces are prevalent. Therefore, a lack of an adsorption capability at high ionic strength will not preclude most foreseeable applications of the code. 


\subsection{APPLICATIONS TO HANFORD DEFENSE WASTE PROBLEMS}

Code validation is the most important and the most difficult of the tasks yet to be completed before the predicted results of MINTEQ2 can stand scientific scrutiny. Many validation studies can be conducted using data from relatively inexpensive laboratory experiments. The aqueous compositions predicted by MINTEQ2 can be compared with easily measurable quantitative aqueous analyses of solutions in contact with appropriate minerals, gases, and adsorption media.

It would also be desirable to compare the predictions given by MINTEQ2 with field experiments. One possibility is to use MINTEQ2 to calculate appropriate distribution coefficients for use in transport codes to predict migration away from waste tanks that have developed leaxs. The distribution coefficient is generally assumed to be a constant through all of the chemical gradients that are dictated by the problem being modeled. This assumption is often untenable because the distribution function for a given element is generally highly dependent on other elements, minerals, Eh and pH. However, by using MINTEQ2, one could calculate redox conditions and obtain more appropriate spatially-and time-dependent distribution coefficients. These could then be used in place of a single distribution coefficient for each element.

If appropriate field data were available, calibration experiments could be performed to condition the geochemical transport model to predict experimental values. For example, if at time $t$ and distance $x$ from the source, element $e$ had an aqueous concentration $c$, the adsorption parameters, mineral assemblages: $\mathrm{pH}$, and Eh could be adjusted so that the predicted concentration would be the same as measured. If this were done for each element and at a number of spatial distances, the model would be calibrated and ready to predict events beyond the range of experimental knowledge. 


\subsection{REFERENCES}

Baes, C. F. and R. E. Mesmer. 1976. The Hydrolysis of Cations. John Wiley and Sons, New York.

Baker, P. A., G. Palmer, and P. W. L. Nichols. 1975. "The Wiswesser Line Formula Notations," in Chemical Information Systems, J. E. Ash and E. Hyde, Eds., El 1 is Horwood, Chichester, Chapter 9.

Bal1, U. W., D. K. Nordstrom and E. A. Jenne. 1980. "Additional and Revised Thermochemical Data and Computer Code for WATEQ2--A Computerized Chemical Model for Trace and Major Element Speciation and Mineral Equilibria of Natural Waters." U.S. Geo1. Survey, Water Res. Invest. 78-116.

Bal1, J. W., E. A., Jenne, and M. W. Cantrel1. 1981. WATEQ3: A Geochemical Model with Uranium Added. U.S. Geol. Survey, Open-FiTe Report 81-1183.

Delegard, C. H. G. S. Barney and S. A. Gallagher. 1983. Effects of Hanford High-Level Waste Components on the Solubility and Sorption of Co, Sr, Np, Pu, and Am. RHO-RE-SA-18P, Rockwell Hanford Operations, Richland, washington.

ERDA. 1977. Alternatives for Long-Term Management of Defense High-Leve? Radioactive Waste, Hanford Reservations, Richland, Washington, Energy Research and Development Adminstration, Washington, D.C.

Felmy, A. R., D. C. Girvin, and E. A. Jenne. 1984. MINTEQ: A Computer Program for Calculating Aqueous Geochemical Equilibria. EPA Contract No. 68-03-3089, Athens Environmental Research Laboratory, Athens, Georgia.

Helgeson, H. C. 1969. "Themodynamics of Hydrothermal Systems at Elevated Temperatures and Pressures." Am. J. Sci. 267:729-804.

Kincaid, C. T., J. R. Morrey and J. E. Rogers. 1984. Geohydrochemical Models for Solute Migration. Volume I: Process Description and Computer Code Selection, Palo Alto, California, Electric Power Research Institute, EA-3417.

Kincaid, C. T., and J. R. Morrey. 1984. Geohydrochemical Models for Solute Migration. Volume II: Preliminary Evaluation of Selected Computer Codes for Modeling Aqueous Solutions and Solute Migration in Soils and Geologic Media. Palo Alto, California, Electric Power Research Institute, EA-

Krupka, K. M. and E. A. Jenne. 1982. WATEQ3 Geochemical Model: Thermodynamic Data for Several Additional Solids. PNL 4276, Pacific Northwest Laboratory, Richland, Washington.

Martel1, A. E. and R. M. Smith. 1976-77. Critical Stability Constants. 4 Vols. Plenum Press, New York. 
APPENDIX A

CURRENT LISTING OF DATA CONVERSION CODE, GEOMIN 
CURRENT LISTING OF DATA CONVERSION CODE, GEOMIN

READ GEOCHEM OATA BASE AND TRANSFORM TO MINTEQ2 DATA BASE

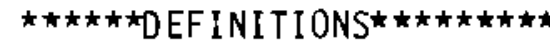

$L=$ LTH REACTION

$J=J T H$ COMPONENT IN LTH REACTION

$K=X T H$ REACTION OF CARO 5

IOYT(L) = MINTEQ2 IDENTIF ICATION

$\operatorname{TYP}(L)=$ TYPE OF REACTION (AQ, SOLID, REDOX, ETC.)

$C X(L)=L O G(K)$

$\operatorname{NCOMP}(L)=$ NUMBER OF COMPONENTS IN LTH REACTION

CH(L) = CHARGE ON PROOUCT OF LTH REACTION

II $(J, L)=$ GEOCHEM INDEX NUMBER OF JTH REACTANT IN LTH REACTION

$I T(J, L)=$ TYPE OF JTH COMPONENET IN LTH REACTION (I AMETAL, $2=L$ IGAND)

$\operatorname{INS}(\mathrm{J}, \mathrm{L})=$ STOICHIOMETRIC COEFFICIENT OF JTH REACTANT IN LTH REACTION LCK $(K)=$ IOLOGK FOR KTH REACTION IN CARD 5

INSA $(J, K)=$ STOICHIOMETRIC COEFFICIENT OF JTH REACTANT IN KTH REACTION $\operatorname{IDSEL}(M, I)=$ GEOCGEM INDEX OF COMPONENT TO SELECT ( $M$ = 1 METAL, $M=2$ LIGANO MINTRA $(M, I)=M I N T E Q 2$ I NDEX CORRESPONDING TO GEOCHEM INDEX I (M=1 METAL $\operatorname{MINCLA}(M, I)=M I N E R A L$ CLASS IFICATION INDEX FOR MINTEQ

$\operatorname{COMNAM}(M, I)=$ NAME CORRESPONDING TO ITH GEOCHEM INDEX ( $M=1$ METAL

$\operatorname{COMSYM}(M, I)=$ CHEMICAL SYMBOL FOR THE ITH GEOCHEM INDEX

GFW $(M, I)=$ GRAM FORMULA WEIGHT OF ITH SPECIES OF MTH TYPE

GFWC(L) \#MOLECULAR WE IGHT OF LTH PRODUCT

$\operatorname{NCHA}(M, I)=\operatorname{NUMBER}$ OF CHARACTERS IN $\operatorname{COMSYM}(M, I)$

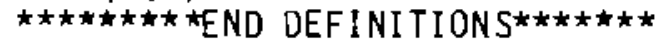

IMPLICIT REAL*8(A-H,O-Z)

CHARACTER $* 8$ COMNAM, SPECIES, TYP, COMSYM, NAM 3

CHARACTER I NAMI, NAMR, NUMB $(10)$, I SIM(12)

CHARACTER $\star 2$ HOL(2D), IASC(12)

CHARACTER*7 IDYT (1000)

CHARACTER* 1 IDYY $(7,1000)$

EQUIVALENCE (IDYT(1), IDYY $(1,1)$ )

CHARACTER*7 MINTRA $(2,99)$

CHARACTER 18 NAMER, NAMO

DIMENSION MINCLA $(2,99)$

DIMENSION NAMI (18), NAMZ (8)

EQUIVALENCE (NAM2(1),NAM3), (NAM1(1),NAMD)

DIMENSION I I $(7,1000), \operatorname{IT}(7,1000), \operatorname{INS}(7,1000), T(7,1000)$

DIMENSION LCK $(9), \operatorname{INSA}(4,9), \operatorname{SPECIES}(2)$

DIMENSION IDSEL $(2,99), \operatorname{COMNAM}(2,99), \operatorname{COMSYM}(2,99)$,

$1 \mathrm{NCHA}(2,99), \mathrm{V}(2,99), \operatorname{ICH}(2,99), \mathrm{GF}(2,99)$

DIMENSION NAMER(1000), TYP(5), CX(1000), CH(1000)

$1, \operatorname{GFWC}(1000), \mathrm{NCOMP}(1000)$

DATA (HOL(I), I=1,20)/' 1',' 2', ' 3',' 4', '5', '6', '7', ' 8', 


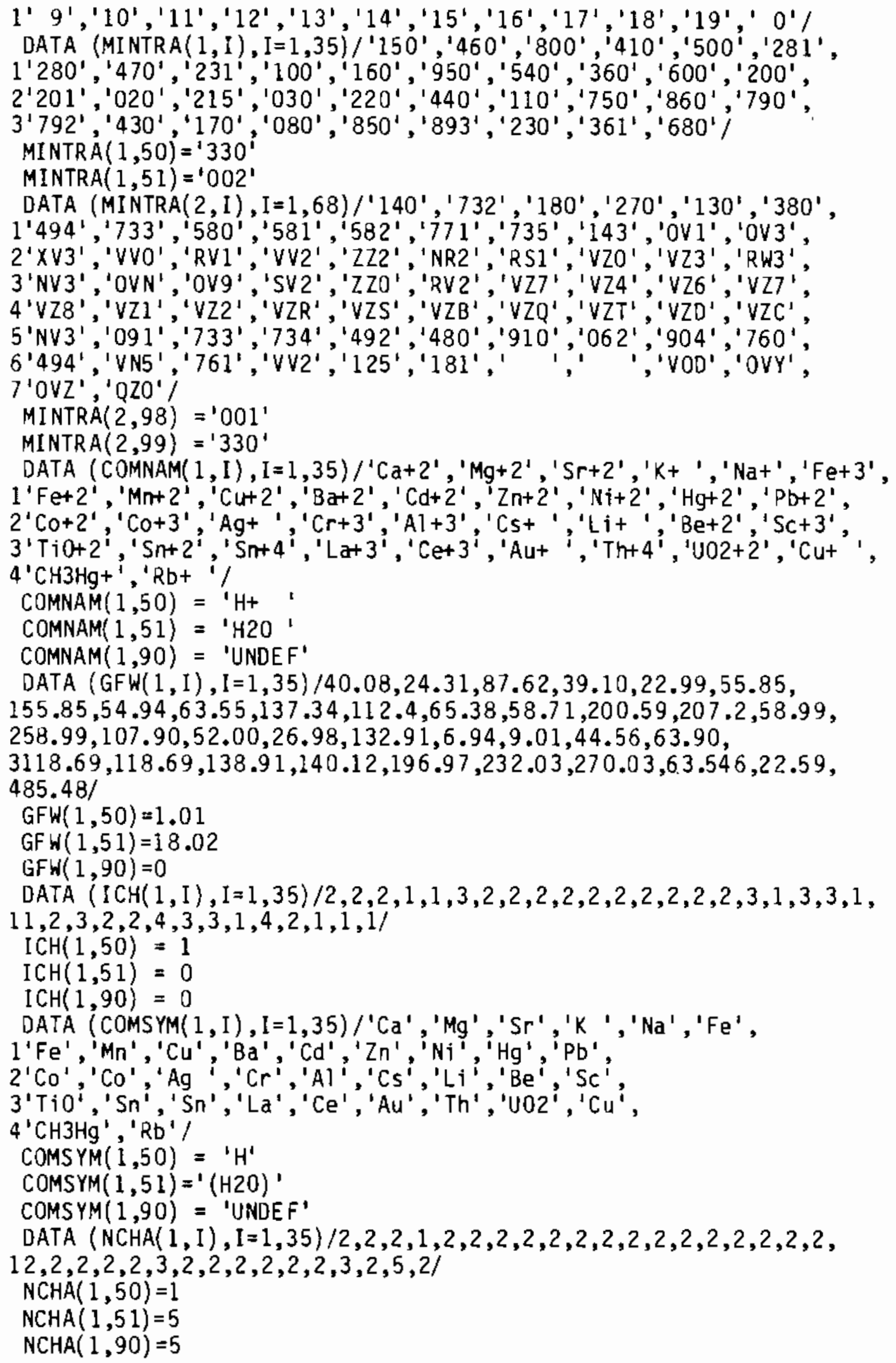




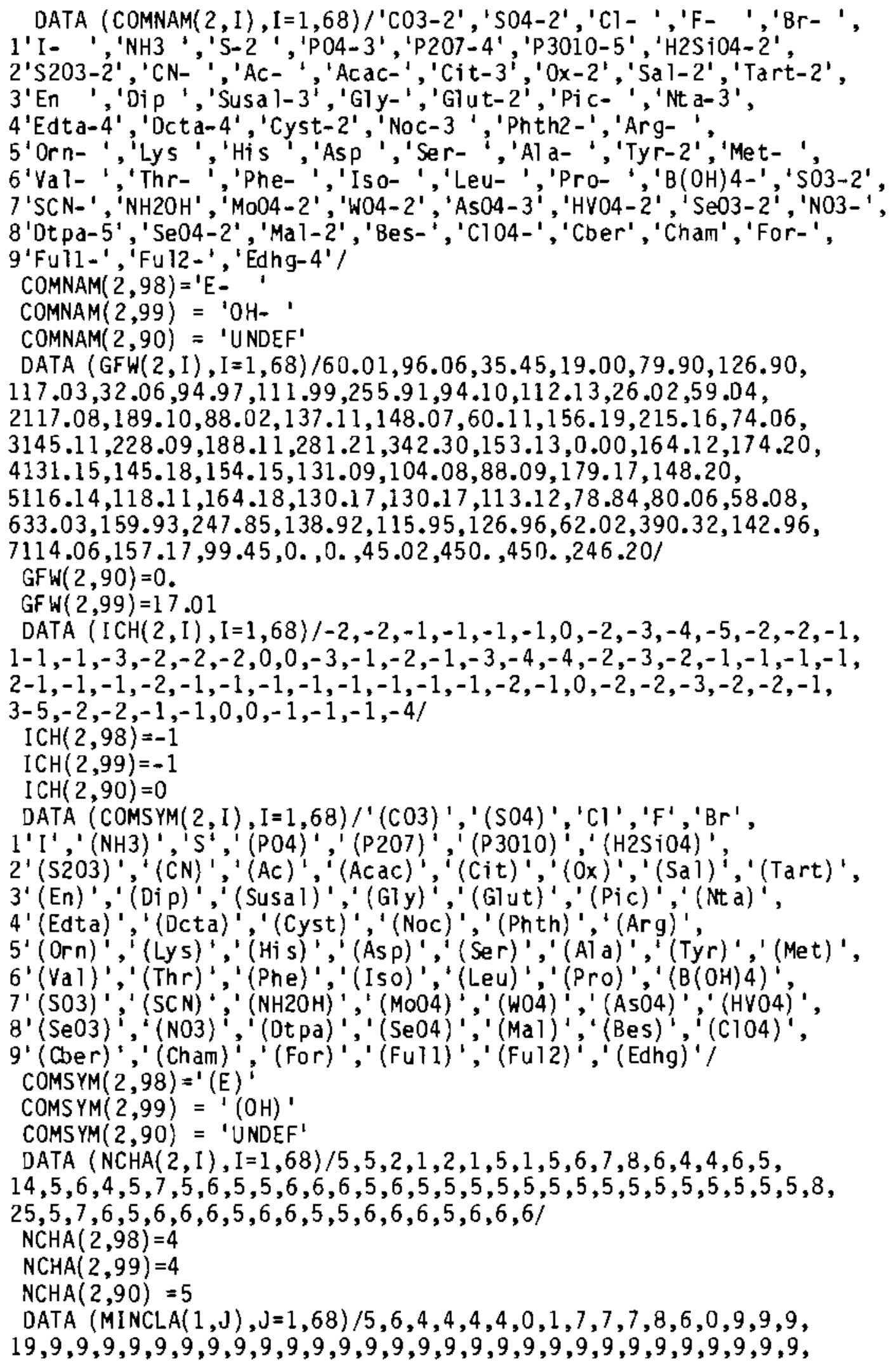




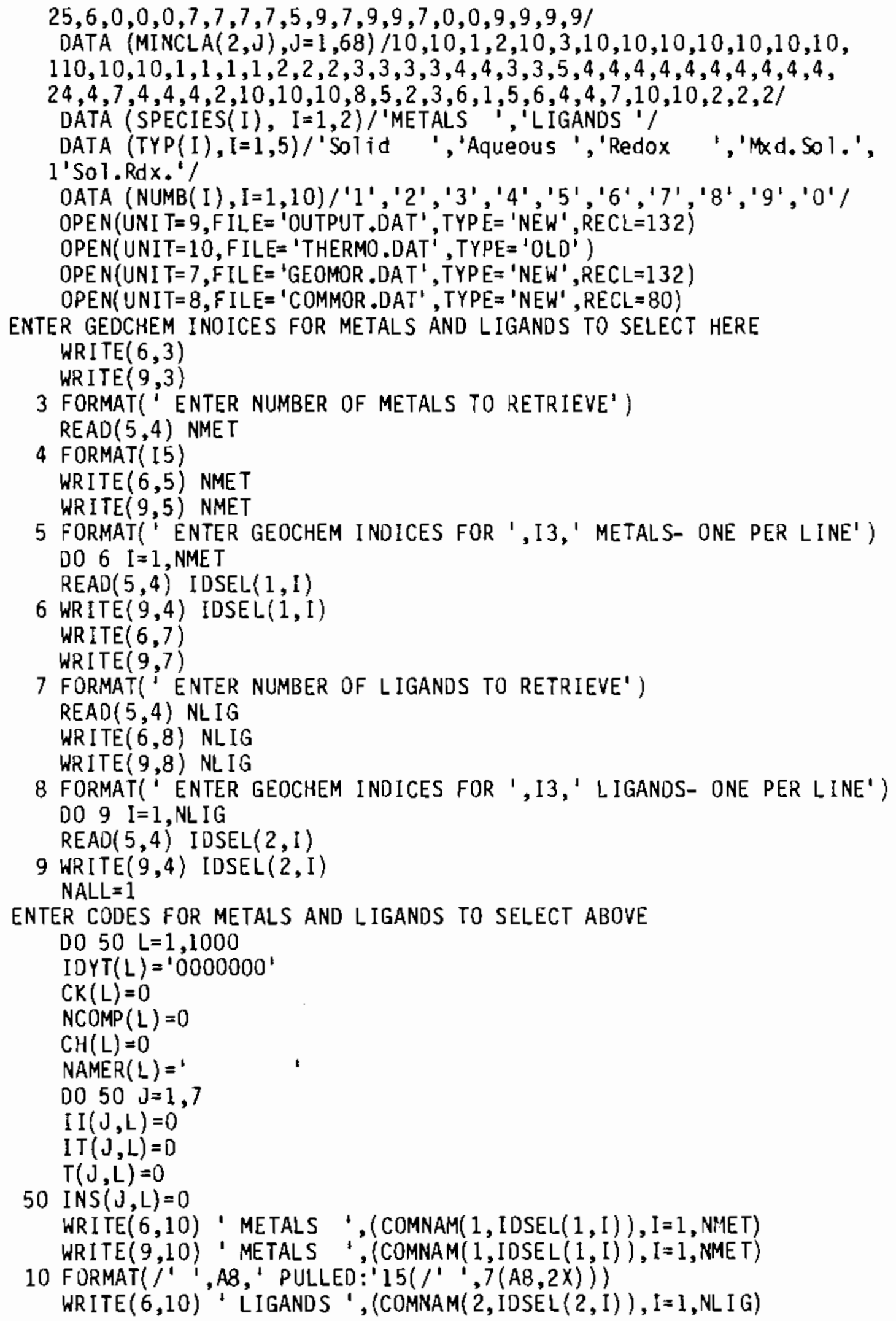




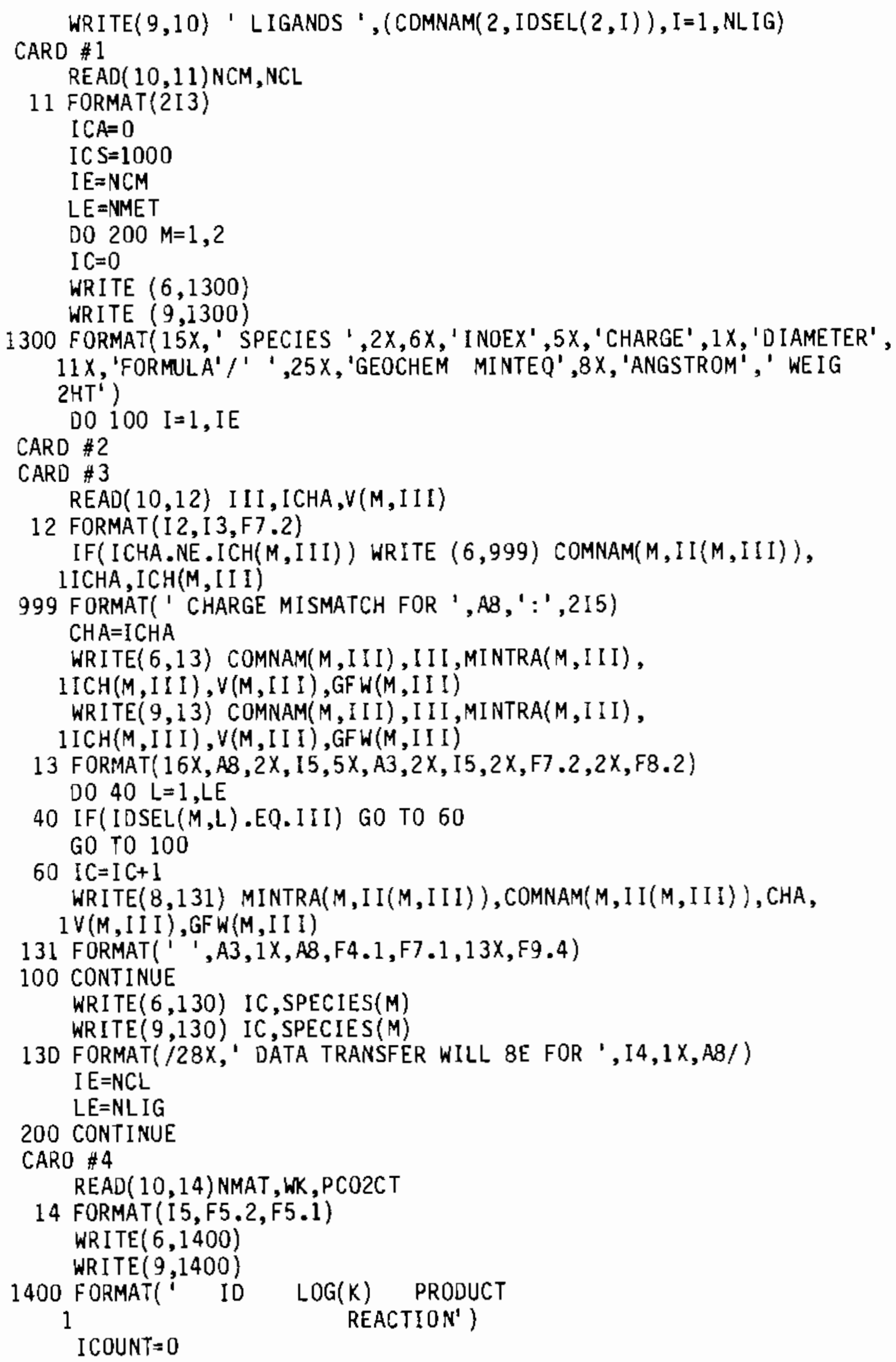




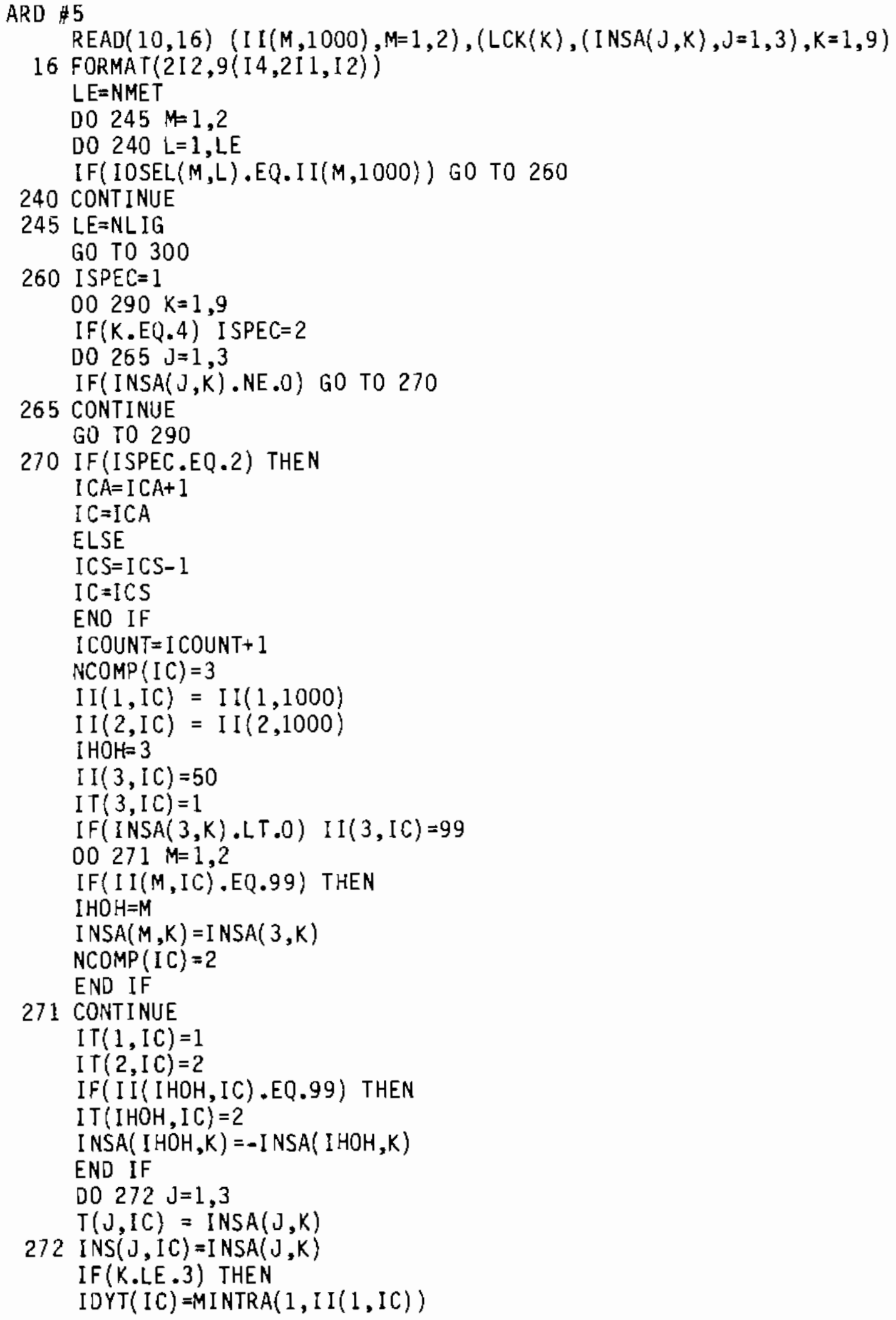


DO 273 KKK=5,3,-1

$273 \operatorname{IDY} Y(K K K, I C)=I D Y Y(X X X-2, I C)$

$\operatorname{IDYY}(1, I C)=\operatorname{NUMB}(\operatorname{MINCLA}(1, \mathrm{II}(2, \mathrm{IC})))$

$\operatorname{IDYY}(2, I C)=\operatorname{NUMB}(\operatorname{MINCLA}(2, I I(2, I C)))$

$\operatorname{IDYY}(3, I C)=\operatorname{MINTRA}(1, I I(1, I C))$

$\operatorname{IDYY}(6, I C)=\operatorname{NUMB}(10)$

$\operatorname{IDYY}(7, I C)=\operatorname{NUMB}(K)$

ELSE

IDYT( IC) $=$ MINTRA $(1, I \mathrm{I}(1, \mathrm{IC}))$

IDYT $(1000)=\operatorname{MINTRA}(2, \mathrm{I} I(2, \mathrm{IC}))$

$\operatorname{IDYY}(4, I C)=\operatorname{IDYY}(1,1000)$

$\operatorname{IDYY}(5, \operatorname{IC})=\operatorname{IDY} Y(2,1000)$

$\operatorname{IDYY}(6, I C)=\operatorname{IDYY}(3,1000)$

$\operatorname{IDYY}(7, \mathrm{IC})=\operatorname{NUMB}(\mathrm{K})$

END IF

$C K(I C)=0.1 * L C X(K)$

$\mathrm{ME}=\mathrm{NCOMP}(\mathrm{IC})$

DO $280 M=1, M E$

$L=M E+1-M$

IF( INS( $L, I C) . E Q .0)$ THEN

$\operatorname{NCOMP}(I C)=\operatorname{NCOMP}(I C)-1$

IF(L.LE.NCOMP (IC) ) THEN

DO $275 \mathrm{~N}=\mathrm{L}, \mathrm{NCOMP}$ (IC)

$T(N, I C)=T(N+1, I C)$

$\operatorname{INS}(N, I C)=\operatorname{INS}(N+1, I C)$

$I T(N, I C)=I T(N+1, I C)$

$\operatorname{II}(N, I C)=I I(N+1, I C)$

$275 \operatorname{IF}(\mathrm{II}(\mathrm{N}, I \mathrm{C}), \mathrm{EQ} \cdot 50.0 \mathrm{R}$.I I (N,IC).$E Q .99)$ IHOH=N

ENO IF

END IF

280 CONTINUE

$\mathrm{CH}(\mathrm{IC})=0$.

GFWC $(I C)=0$.

DO $281 \mathrm{~J}=1, \operatorname{NCOMP}(\mathrm{IC})$

$G F W C(I C)=G F W C(I C)+I N S(J, I C) * G F W(I T(J, I C), I I(J, I C))$

$281 \mathrm{CH}(\mathrm{IC})=\mathrm{CH}(\mathrm{IC})+\operatorname{INS}(\mathrm{J}, \mathrm{IC}) \star \operatorname{ICH}(\mathrm{IT}(\mathrm{J}, \mathrm{IC}), \mathrm{I} I(\mathrm{~J}, \mathrm{IC}))$

NAMD $={ }^{\prime} \mathrm{K}$

I $E=2$

DO $284 \mathrm{~J}=1, \operatorname{NCOMP}$ (IC)

$N A M 3=\operatorname{COMS~YM}(\mathrm{I} T(\mathrm{~J}, \mathrm{IC}), \mathrm{I} I(\mathrm{~J}, \mathrm{IC}))$

IS $=$ IE

$I E=I E+N C H A(I T(J, I C), I I(J, I C))$

IF(IE.GT.18) GO TO 285

$\mathrm{N}=1$

DO $283 \mathrm{I}=\mathrm{IS}, \mathrm{IE}$

$283 \mathrm{~N}=\mathrm{N}+1$

$\operatorname{NAMI}(\mathrm{I})=\operatorname{NAM} 2(\mathrm{~N})$

$\operatorname{IF}($ INS $(\mathrm{J}, I \mathrm{C}) . \mathrm{GT} .1)$ THEN

I $S=I E$

$I E=I E+1$

NAML $($ I S $)=\operatorname{NUMB}($ I ABS $($ INS $(\mathrm{J}$, IC $)))$ 


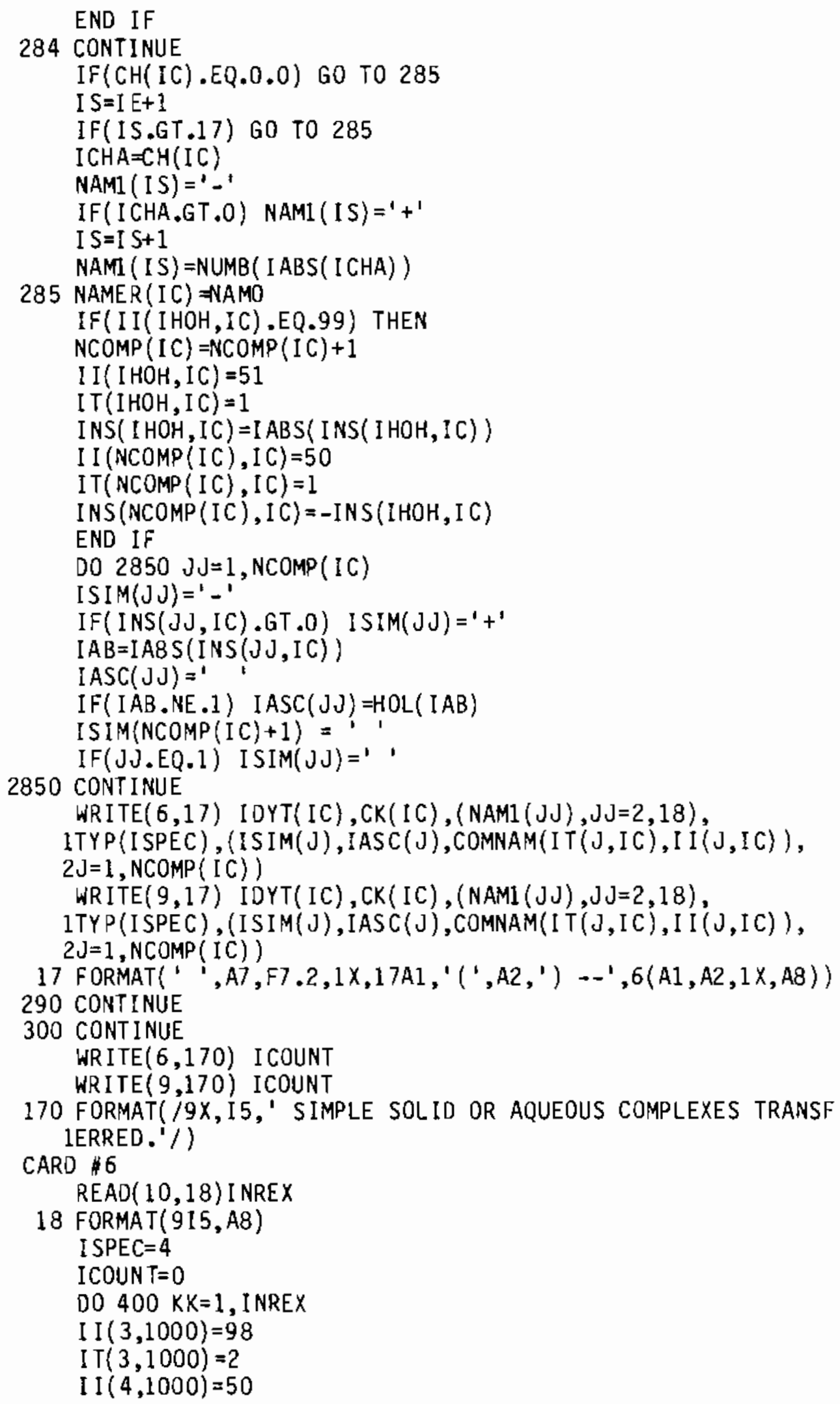




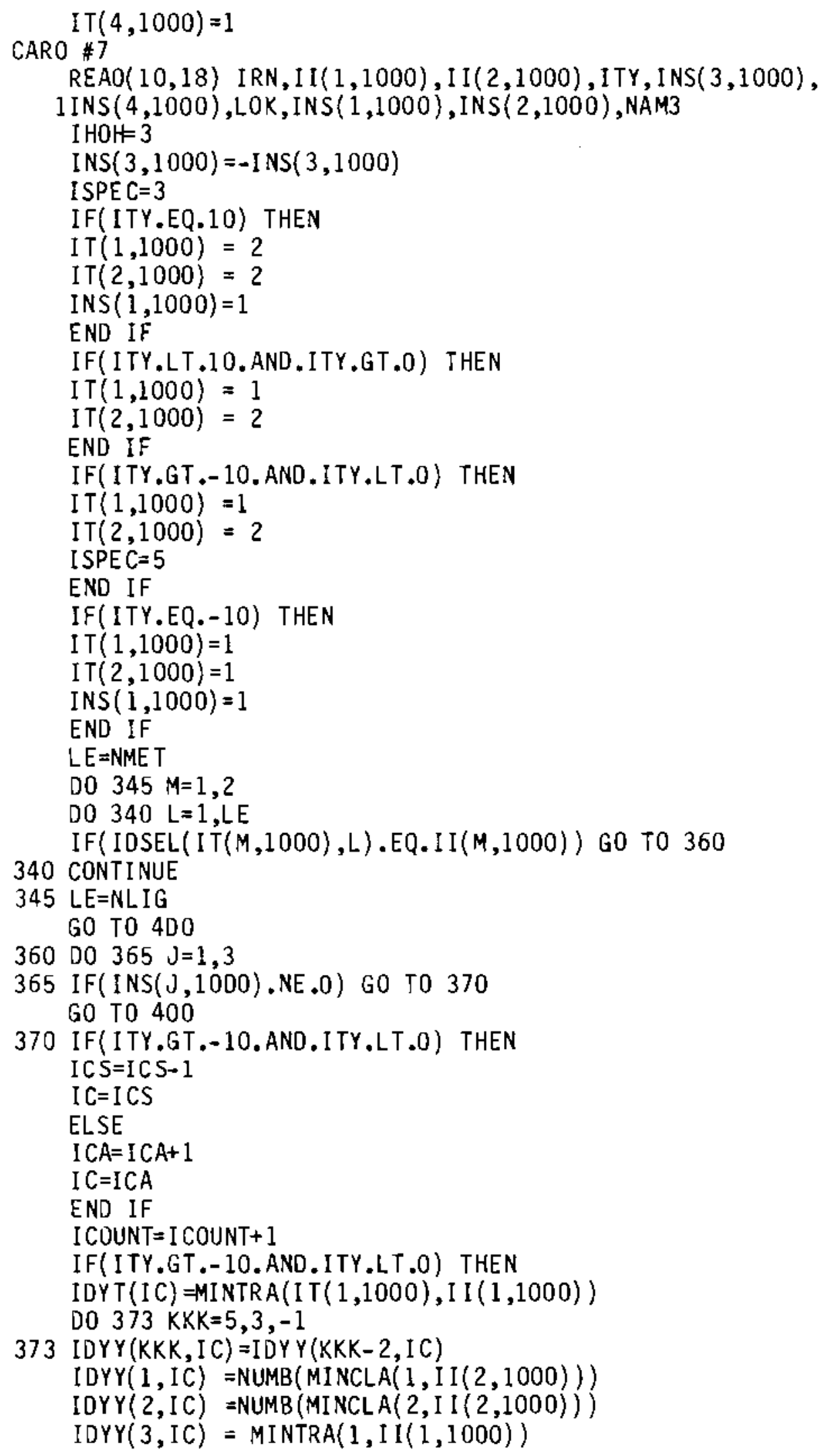




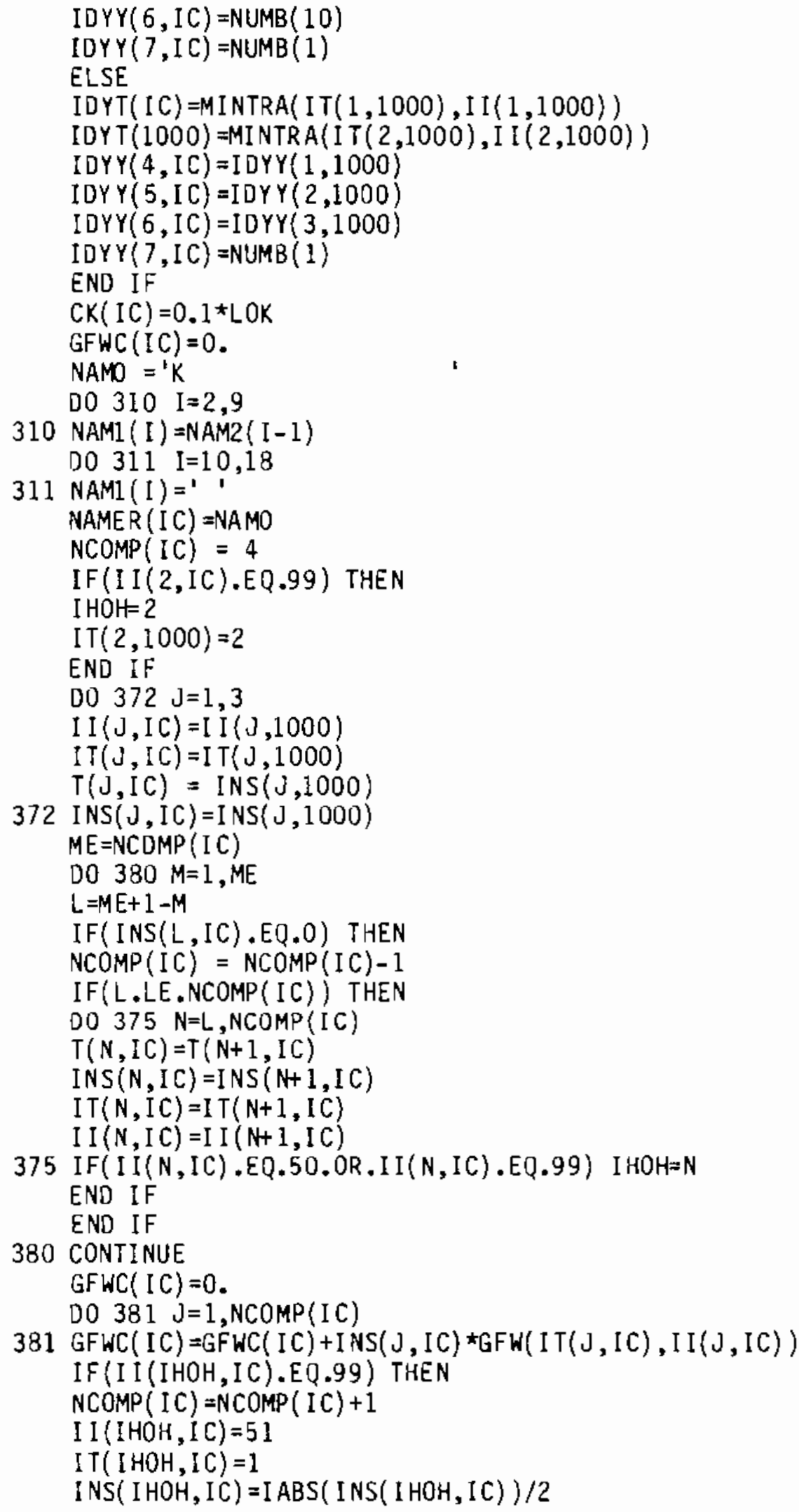




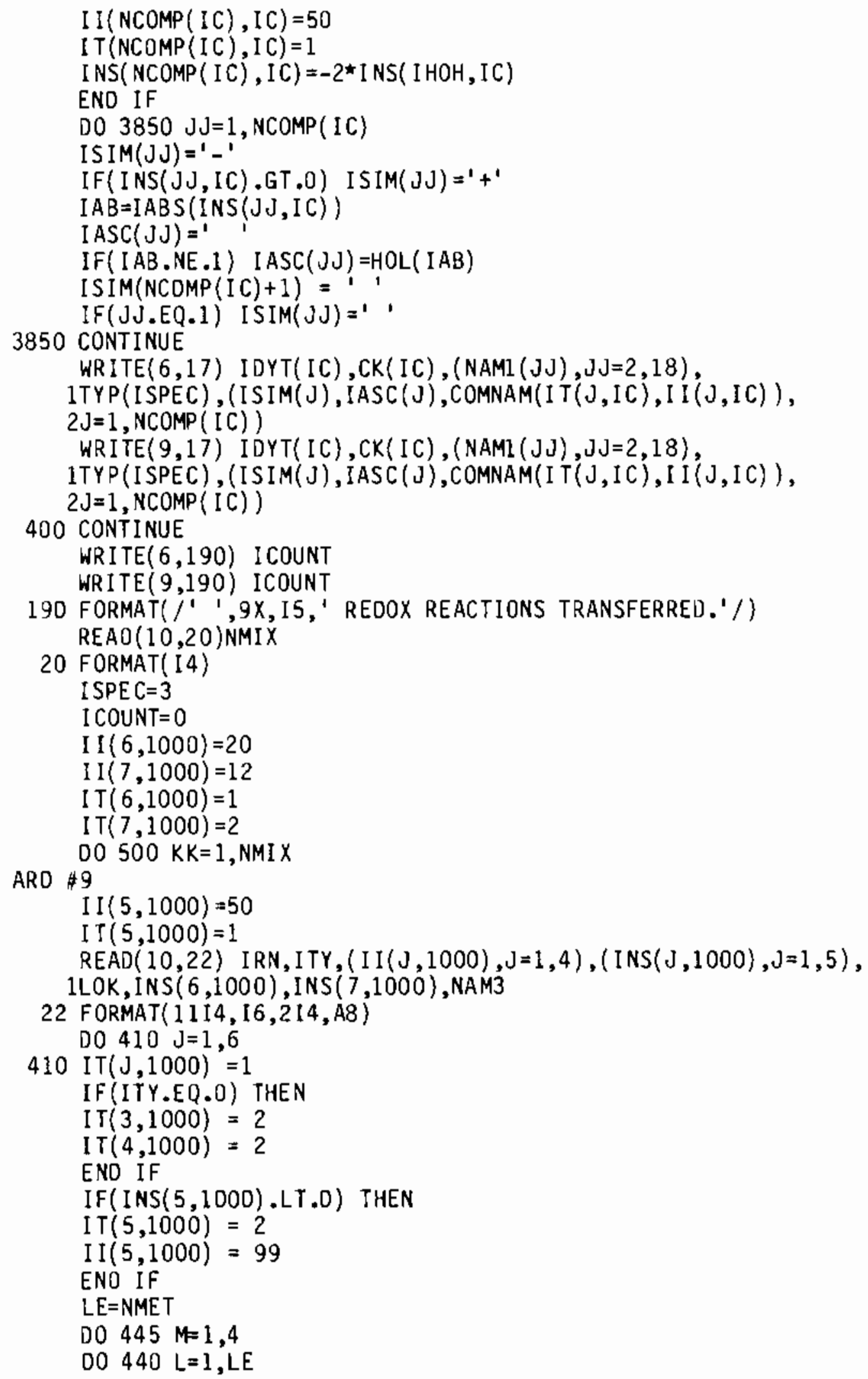




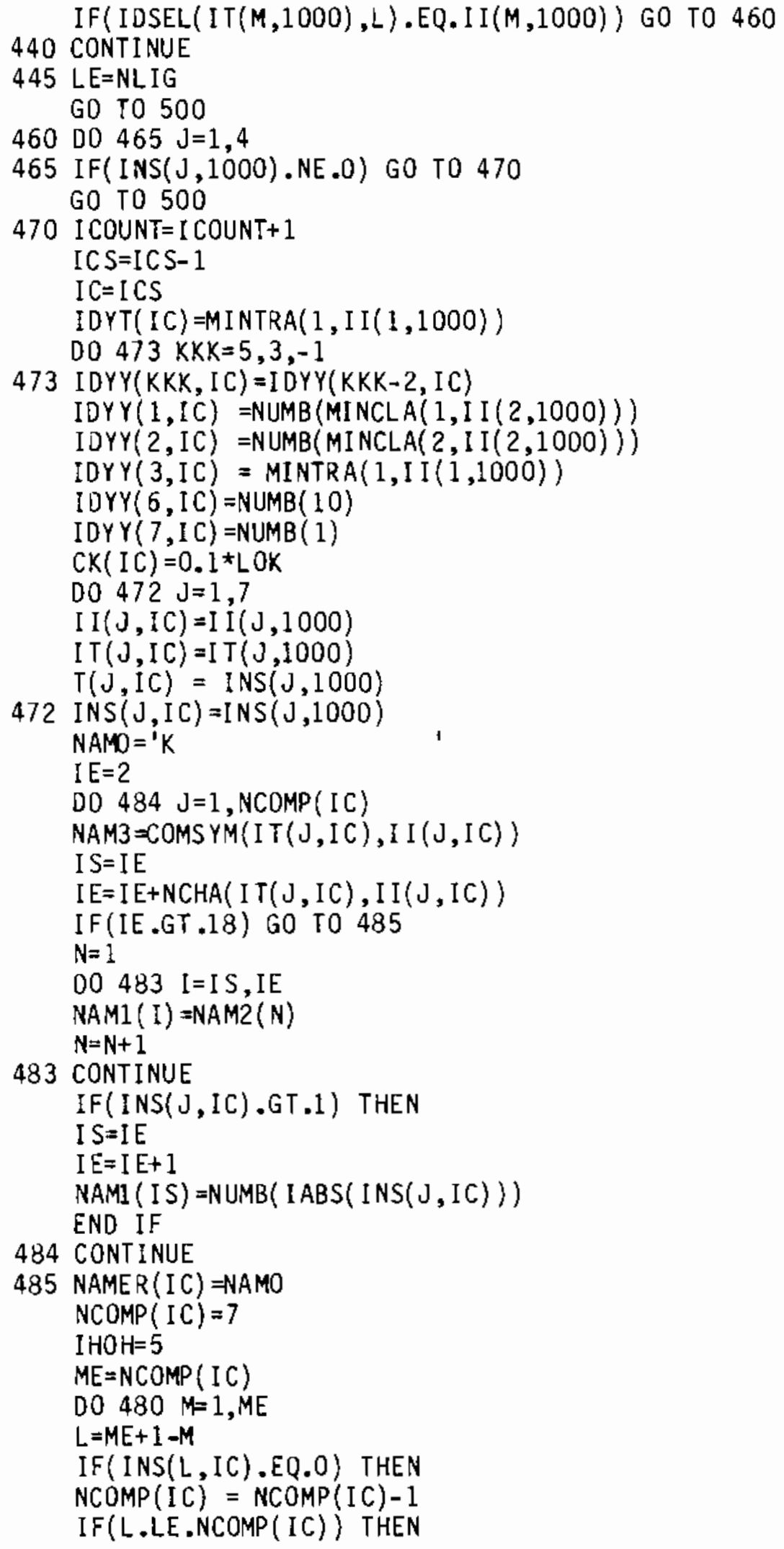




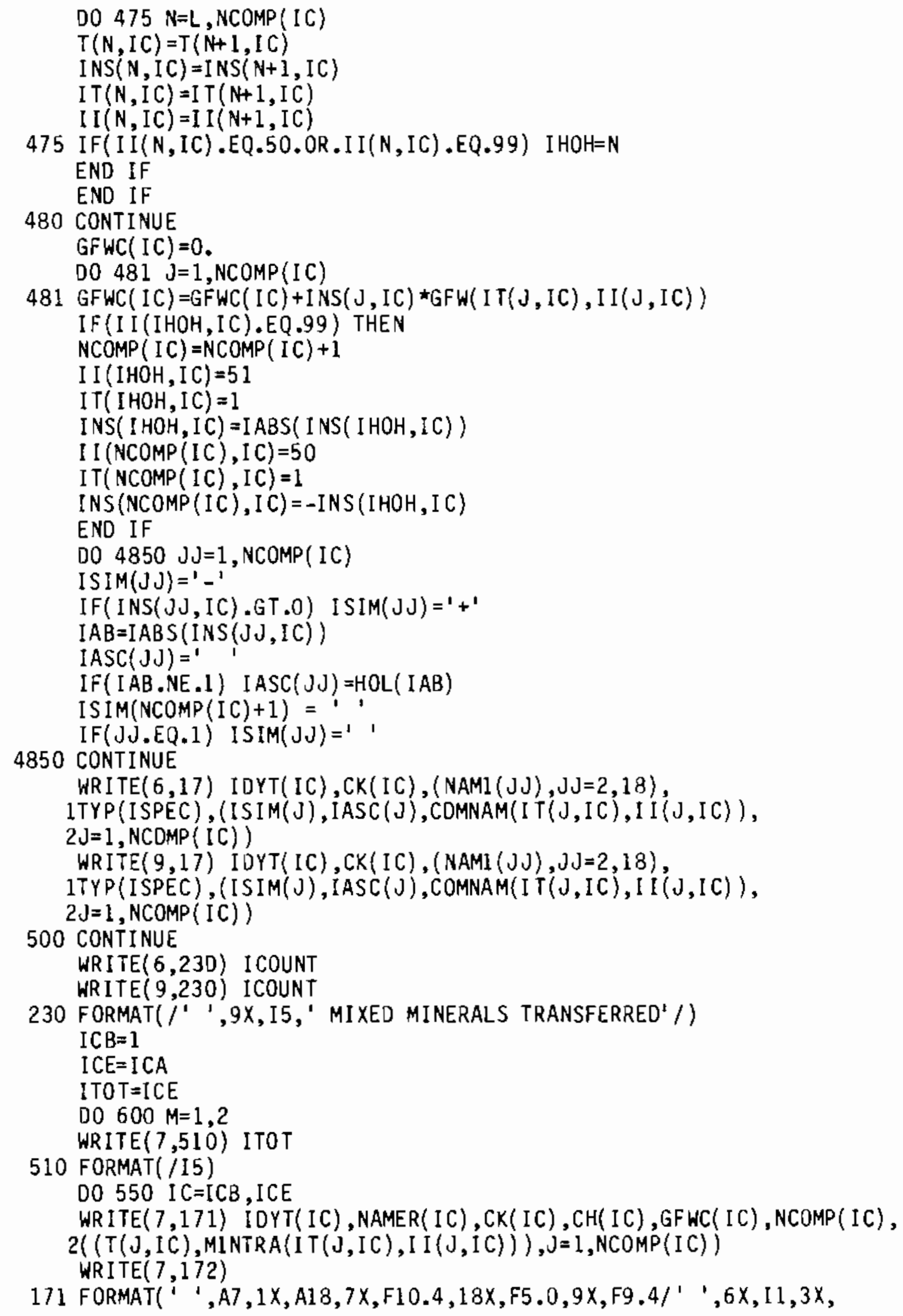


$18(F 7,3,1 \times, A 3,3 X))$

172 FORMAT(/' DATA FROM GEOCHEM (SPOSITO \& MATTIGOO)')

550 CONTINUE

$I C B=I C S$

ICE $=999$

I TOT $=1000-I \mathrm{CS}$

600 CONTINUE

STOP

ENO 


\section{DISTRIBUTION}

No. of

Copies

OFFSITE

30 DOE Technical Information Center

G. Sposito

Department of Soils

University of California Riverside

Riverside, CA 92502

\section{DNSITE}

Hanford Engineering Development Laboratory

R. E. Lerch

7 Richland Operations Office

E. A. Bracken

M. Dayani

G. Drten

K. W. Bracken

M. W. Shupe

J. ก. White

J. K. W. Wukelic

5 Rockwell Hanford Operations

R. E. Isaacson

J. F. Relyea

R. C. Routson

J. C. Sonnichsen

D. E. Wood
No. of

Copies

United Nuclear Industries

0. R. Pratt

33 Pacific Northwest Laboratory

D. W. Dragnich

J. L. Downs-Berg

M. J. Fayer

J. Fruchter

G. W. Gee

M. 1. Grahan

H. A. Haerer

J. N. Hartley

P. C. Hays

K. Krupka

J. R. Morrey (10)

S. Peterson

R. J. Serne

C. S. Simmons

J. A. Sottlemyre

G. P. Streile

R. Wildung

Technical Information (5)

Publishing Coordination (2) 


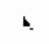

, 